\title{
A Comparison of Maceral and Microlithotype Indices for Interpretation of Coals in the Samarinda Area, Lower Kutai Basin, Indonesia
}

\author{
Chaw Thuzar Win, ${ }^{1,2}$ Donatus Hendra Amijaya, ${ }^{1}$ Sugeng Sapto Surjono, ${ }^{1}$ \\ Salahuddin Husein, ${ }^{1}$ and Koichiro Watanabe ${ }^{3}$ \\ ${ }^{1}$ Department of Geological Engineering, Gadjah Mada University, Yogyakarta, Indonesia \\ ${ }^{2}$ Department of Geology, East Yangon University, Yangon, Myanmar \\ ${ }^{3}$ Department of Earth Resources Engineering, Kyushu University, Fukuoka, Japan
}

Correspondence should be addressed to Chaw Thuzar Win; chawchaw.geol@gmail.com

Received 21 April 2014; Revised 11 July 2014; Accepted 1 August 2014; Published 31 August 2014

Academic Editor: Thierry Sempere

Copyright (C) 2014 Chaw Thuzar Win et al. This is an open access article distributed under the Creative Commons Attribution License, which permits unrestricted use, distribution, and reproduction in any medium, provided the original work is properly cited.

\begin{abstract}
Strata of the Middle Miocene Balikpapan Formation from the Lower Kutai basin are well exposed in a section near the Samarinda city, East Kalimantan, Indonesia. The succession is characterized by thick sandstone bodies alternating with shales and coal beds. A $250 \mathrm{~m}$ thick composite section of exposed sediments (not including the soil interval) was measured, from which 25 coal samples were collected. Petrographic, microlithotype, and maceral analyses were performed in order to determine the depositional environment of the Samarinda coals. In order to assess the development of paleomires, coal facies diagrams were obtained from microlithotype and maceral composition. According to the organic petrologic results, the Samarinda coals represent a highly degraded humodetrinite-rich group deposited from terrestrial into telmatic condition of peat formation with vegetation characteristics of highly degraded woody forest type evolved under alternate oxic to anoxic moor conditions. These formed with intermittent moderate to high flooding as the paleopeat environment shifted from mesotrophic to ombrotrophic.
\end{abstract}

\section{Introduction}

The Kutai basin is the largest Tertiary basin in Western Indonesia. Deltaic sedimentation has been continuous in the Kutai basin from Late Oligocene to the present day as represented by the modern Mahakam delta and upstream in the continent [1]. There is a structural deepening of formations in the basin to the east to the Mahakam area, where hydrocarbon fields are situated (Figure 1).

A composite log of $250 \mathrm{~m}$ (not including the soil interval) of exposed sediments of the Balikpapan formation was made on August 6 to 13, 2012. The sediments and coal were examined at 10 sites and the locations of which within the study area are shown in (Figure 1). This section has been previously investigated by Cibaj, 2010 and Cibaj et al., 2007 $[1,2]$. They showed Middle Miocene Seravallian age (NN5 to NN11 nanoplankton zones). The purpose of the present study is to assess the organic petrology and the interpretation of coal facies and depositional environment of coals of the Samarinda area, Lower Kutai basin, Indonesia.

In the study of coals, maceral analysis and microlithotype analysis are used to assess the environment of deposition when paleobotanical data are scarce or absent. This implementation of maceral ratios such as the Vegetation Index and Ground water Index tried to overcome this hurdle, but this approach has not been well correlated through the study of highly degraded younger tropical coal with high humodetrinite. What does the petrographic composition of these younger tropical coals convey to us? A simple modification of GWI-VI diagram of Calder et al., 1991 [3] and poor correlation of interpretation of coal depositional milieus of peat formation based on microlithotype composition alone are illustrated in this paper. 


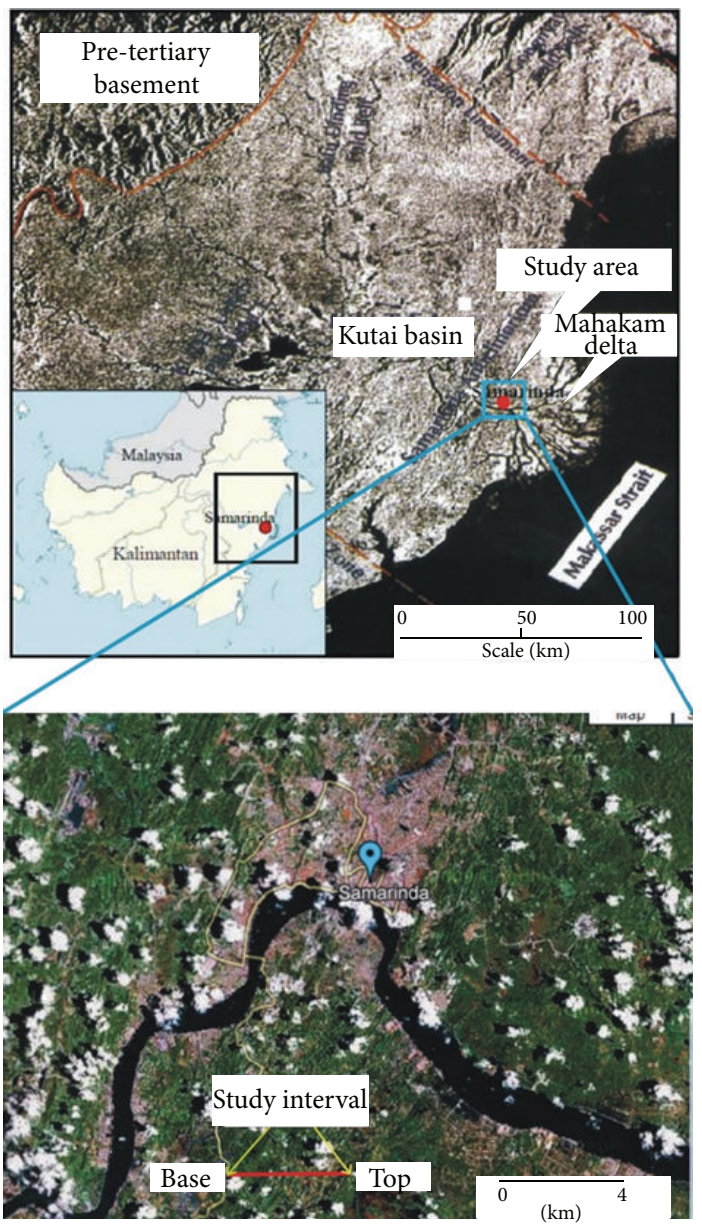

(a)
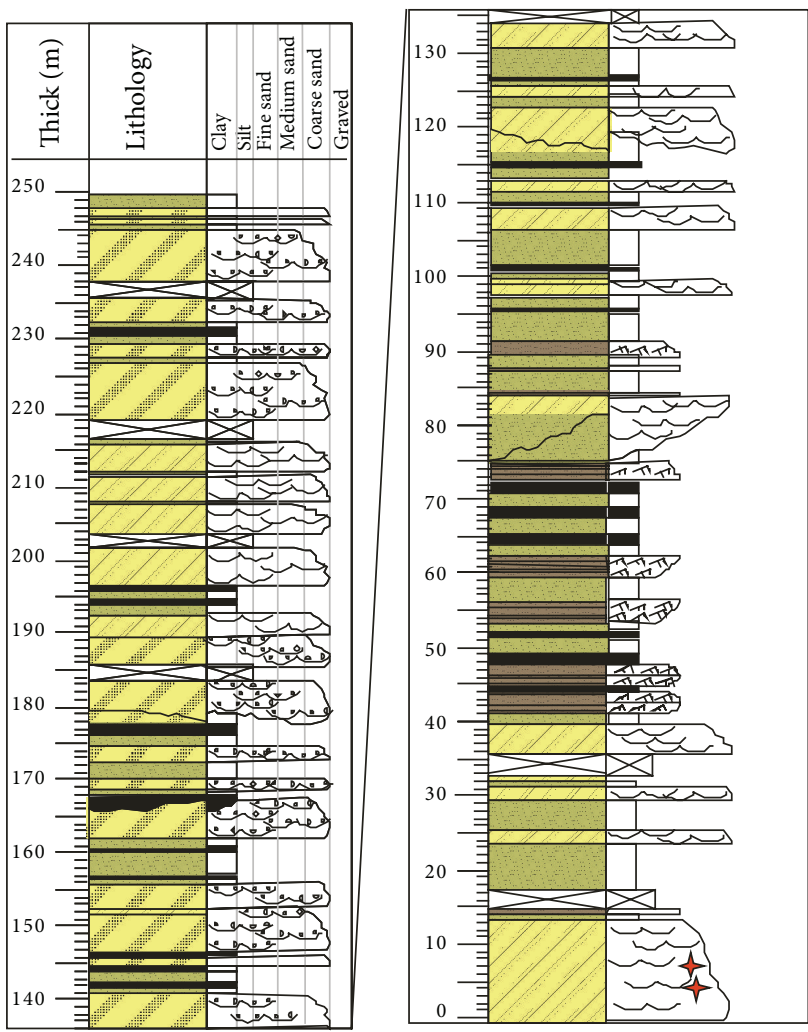

Conglomerate and sandstone

Coarse-to-medium-grained sandstone with trough cross-bedding

Fine-grained sandstone

Claystone

Coal

m Ripple

Trough cross-bedding

in Gravelly sandstone

$\sim$ Trough cross-bedding

(b)

FIGURE 1: (a) Location and regional geology of the studied area and (b) summary outcrop log and coal bearing interval of the studied interval.

In this study, the recommended definition of Gore, 1983 [4] and Moore, 1987 [5] is followed for the terms which are used in the wetland ecosystem. The most fundamental distinction of mire type is based on hydrology, specially the source of water and ions. Rheotrophic mires receive recharge from both groundwater and rainfall, whereas ombrotrophic mires are solely rain-fed. The term minerotrophic, which refers to a mineral-rich ground water source, is loosely analogous to rheotrophic. An intermediate classification of mesotrophic applies to mires tending toward ombrotrophic conditions. Ombrotrophic mires are termed bogs; rheotrophic mires can be subdivided into fen or bog; fen and swamp are further defined on the basis of vegetation. Limnic is a condition of peat formation occurring on or in deep water by free-floating or deeply rooted plants and telmatic is a process of peat formation at the water table due to plants growing under conditions of periodic flooding whereas terrestrial means peat formation above the general water table.

\section{Regional Geology and Coals of the Kutai Basin}

The Early Paleogene rifting along the margins of Sundaland, which is a back arc setting of the Indian Ocean plate, resulted in a number of shallow basins [6, 7]. Friederich et al., 1999 [8] have worked out, in detail, the coal bearing sequences of Indonesia. Eastern Kalimantan is one of the major coal basins in Indonesia having economic coal deposits where the thickest coal seams are attributed to high stand system tracts (HST) and transgressive system tracts (TST) which contributed to their optimum preservation potential, Davis et al., 2007 [9].

According to Longley, 1997 [10], three major episodes of peat formation took place within Tertiary of Indonesia. The first episode took place during Early-to-Middle Eocene. This resulted in the rifting in Java, Kalimantan, and Sulawesi. The second episode began in the Late Oligocene in Sumatra and Java. This episode was associated with thermal subsidence 
and transgression. The third episode occurred during global high stand of Middle Miocene and extended by Late Miocene to Pleistocene times over the whole region. This episode is marked by the development of major prograding deltas all along their margins. This can be seen in Kutai basin in the Southeast Kalimantan (Figure 1).

Coal rank in the Kutai basin is low to moderate, ranging from lignite to high-volatile bituminous, the latter described as bright and lustrous. Vitrinite reflectance of shallow coal from coal mining areas is typically 0.45 to $0.63 \%$ [11]. This is higher than other Indonesian coal basins. In the study area in Samarinda, identified reserves of high-volatile bituminous and subbituminous coals from Loa Kulu and Loa Haur are 35 million tons, but these reserves are in scattered small areas. In the Badak Syncline there are 428 million tons of reserves in 14 seams, mostly of subbituminous rank coal [12].

\section{Materials and Methods}

Rock units of Middle Miocene are well exposed in a section near Samarinda City, East Kalimantan, Indonesia. This stratigraphic section is a part of the Samarinda Anticlinorium and located between Separi Anticline and Prangat Thrust. The outcrops constituting the section are currently easily accessible and are situated close to the main road to Samarinda, near and around the new stadium built in 2007. There are about nineteen coal seams in this log and coal samples were collected from all coal bearing intervals of the surface exposures and represent all seams from the base to the top of the section. The macroscopic appearance of the coal was determined using the lithotype classification system from Diessel, 1992 [13]. From each exposed locations of the Samarinda area, about $2 \mathrm{~kg}$ of coal samples were collected. They were crushed, to reduce in quantity to prepare composite samples. These samples were then subjected to petrographic analyses. The samples were crushed to -20 mesh size and were embedded in a plastic mold (diameter $3 \mathrm{~cm}$ ) using epoxy resin as an embedding medium. After hardening, the samples were ground and polished for petrographic analysis. The sample preparation and microscopic examination generally followed the procedures described by Taylor et al., 1998 [14].

For the microlithotype analysis, more than 200 points with a distance of $1 \mathrm{~mm}$ were counted and the methodology given by Stach, 1982 [15], was followed.

Vitrinite reflectance measurement was performed on a Zeiss universal microscope equipped with SF photomultiplier. Thirty readings of random vitrinite reflectance were taken on each sample at a wavelength of $546 \mathrm{~nm}$. Reflectance was measured on huminite macerals. The mean random vitrinite reflectance values were then calculated using a computer program.

During maceral analysis, 500 points with a minimum distance of $0.2 \mathrm{~mm}$ between each point were counted on each polished sample. The analysis was conducted in reflected white light and in fluorescence irradiated by blue/violet light under oil immersion using a Zeiss Axioplan microscope.

Coal rank determination and maceral classification followed Taylor et al., 1998 [14]. Mineral matter was only divided into two groups, pyrite and other minerals, since other minerals, such as clay minerals, quartz, or carbonate, were only found in very small amounts.

\section{Results and Discussions}

4.1. Macroscopic Appearance of the Coals (Lithotypes). The coal seams in the studied stratigraphic section are generally dipping to the east (amount 30-45 degree). Most of the coal seams are predominantly composed of the bright coal and banded bright coal lithotypes. In the vertical section, only the lower-half part contains dull bands and gradually changes into banded bright coal and bright coal to the upper part. Cleats are best developed and most continuous in bright coal bands but are poorly expressed in dull coals. The megascopic characteristics of coal samples along with their location and details of the coal seams are summarized in Table 1.

4.2. Maceral Composition. The maceral analysis shows that almost all coals are dominated by huminite; liptinite and inertinite group macerals are less abundant. The total liptinite content varies between 0 vol. $\%$ and 28.7 vol. $\%$, while total inertinite ranges from 1.9 vol. $\%$ to 25 vol.\%. The huminite content, however, is substantially high and varies between 46.3 vol.\% and 97 vol.\%. Minerals are found (0-25.2 vol.\%); most of them are pyrite. Table 2 shows the maceral composition of each seam. The huminite is dominated by humodetrinite mainly represented by attrinite with 52.2 vol. $\%$ to 94.6 vol.\%, while densinite occurs in small quantity.

Humotelinite is mainly represented by ulminite, while textinite is absent. Humocollinite is, however, low in concentration and constitutes corpohuminite. In general, huminite is present in two forms, huminite bands and huminite groundmass. The huminite bands not only are formed by humotelinite macerals, but also in many cases are formed by thick layers of humodetrinite that are interbedded with ulminite layers. Humodetrinite is present mostly as groundmass surrounding liptinite or inertinite particles. Humocollinite is disseminated throughout the coals mostly as corpohuminite of globular or tabular shape.

Though having less concentration of liptinite, only one sample (Seam 10) has a high liptinite content 28.7 vol.\%. The common liptinite macerals in the coals are sporinite, cutinite, resinite, alginite, and suberinite. Cutinite content is 0.0 vol. $\%$ to 5.8 vol. \% and sporinite is found only in small amount. Resinite occurs in 0.0 vol.\% to 15.35 vol.\%.

The maximum content of resinite is also found in Seam 10. Resinite macerals in the studied coal appear mostly as isolated small globular bodies, but some small resinite layers also occur. Under fluorescence they have pale-brownish-yellow colour. Occasionally some resinite bodies appear as groups in distinct layers. Resinite macerals are commonly associated with humodetrinite, and alginites were found only in trace amounts of $0.4-1$ vol.\% in some samples. Alginite has very intense yellow fluorescence colour.

The suberinite appears as cell wall tissue and shows well preserved cortical cells and is characterized by dark colour in reflected light and a greenish to pale yellow in fluorescent 
TABLE 1: Summary showing location and megascopic characters of coal seams. Note seam 1 is the lowermost part of the stratigraphic position.

\begin{tabular}{|c|c|c|}
\hline $\begin{array}{l}\text { Sample } \\
\text { number }\end{array}$ & $\begin{array}{l}\text { Measure section } \\
\text { location }\end{array}$ & Basic features of coal sample \\
\hline Seam 1 & \multirow{5}{*}{$\begin{array}{c}\text { From S } 0^{\circ} 35^{\prime} 9.74^{\prime \prime} \\
\text { E } 117^{\circ} 6^{\prime} 45.95^{\prime \prime} \\
\text { to } \\
\text { S } 0^{\circ} 35^{\prime} 48.04^{\prime \prime} \\
\text { E } 117^{\circ} 5^{\prime} 50.94^{\prime \prime}\end{array}$} & $\begin{array}{l}\text { Exposed thickness is } 1.5 \mathrm{~m} \text {, banded bright } \\
\text { coal }\end{array}$ \\
\hline Seam 2 & & $1 \mathrm{~m}$, dull coal \\
\hline Seam 3 & & $1.5 \mathrm{~m}$, banded bright coal \\
\hline Seam 4 & & $1.5 \mathrm{~m}$, banded dull coal \\
\hline Seam 5 & & $1.5 \mathrm{~m}$, banded dull coal \\
\hline Seam 6 & \multirow{6}{*}{$\begin{array}{c}\text { From S } 0^{\circ} 35^{\prime} 48.04^{\prime \prime} \\
\text { E } 117^{\circ} 5^{\prime} 50.94^{\prime \prime} \\
\text { to } \\
\mathrm{S} 0^{\circ} 35^{\prime} 8.37^{\prime \prime} \\
\mathrm{E} 117^{\circ} 7^{\prime} 16.62^{\prime \prime}\end{array}$} & $0.5 \mathrm{~m}$, bright coal \\
\hline Seam 7 & & $1.5 \mathrm{~m}$, bright coal \\
\hline Seam 8 & & $0.5 \mathrm{~m}$, bright coal \\
\hline Seam 9 & & $0.4 \mathrm{~m}$, bright coal \\
\hline Seam 10 & & $0.5 \mathrm{~m}$, bright coal \\
\hline Seam 11 & & $0.3 \mathrm{~m}$, dull coal \\
\hline Seam 12 & \multirow{7}{*}{$\begin{array}{c}\text { From S } 0^{\circ} 35^{\prime} 8.37^{\prime \prime} \\
\mathrm{E} 117^{\circ} 7^{\prime} 16.62^{\prime \prime} \\
\text { to } \\
\mathrm{S} 0^{\circ} 34^{\prime} 59.09^{\prime \prime} \\
\mathrm{E} 117^{\circ} 7^{\prime} 32.21^{\prime \prime}\end{array}$} & $0.5 \mathrm{~m}$, bright coal \\
\hline Seam 13 & & $0.5 \mathrm{~m}$, banded bright coal \\
\hline Seam 14 & & $0.5 \mathrm{~m}$, bright coal \\
\hline Seam 15 & & $0.5 \mathrm{~m}$, bright coal \\
\hline Seam 16 & & $0.5 \mathrm{~m}$, bright coal \\
\hline Seam 17 & & $1 \mathrm{~m}$, banded bright coal \\
\hline Seam 18 & & $1.5 \mathrm{~m}$, bright coal \\
\hline Seam 19 & $\begin{array}{l}\mathrm{S} 0^{\circ} 34^{\prime} 53.97^{\prime \prime} \\
\mathrm{E} 117^{\circ} 7^{\prime} 42.73^{\prime \prime}\end{array}$ & $1.5 \mathrm{~m}$, banded bright coal \\
\hline
\end{tabular}

light. Suberinite constitutes 0.0 vol. $\%$ to 8.4 vol.\% ( $\mathrm{mmf}$ basis). The highest content of suberinite occurs also in Seam 10. Inertinite occurs in low concentration and constitutes of fusinite, semifusinite, funginite, and inertodetrinite.

The cell lumens of fusinite and semifusinite are occasionally occupied by argillaceous mineral matter. Large sized funginites, up to $395 \mu \mathrm{m}$ have also been observed. Minerals are found (0-25.2 vol.\%); most of them are pyrite. Some clay, carbonate, and quartz are observed as well. Fusinite is predominant whereas semifusinite and inertodetrinite are found in these coals. Micrinite and macrinite are rare. Fusinite occurs in the form of discrete lenses and bands. The common fusinite bands have thicknesses from $0.07 \mathrm{~mm}$ up to more than $1 \mathrm{~mm}$. Inertodetrinite is disseminated throughout the coals and comprises usually $0.0-7.45$ vol.\%. Funginite occurs $1.0 \mathrm{vol} . \%$ to $11.3 \mathrm{vol}$ \% of studied coals. This maceral is distributed in almost all the samples usually in the oval form funginite. The tubular form of funginite is rarely present. Funginite occurs as single bodies or as colonies. Its pores are often filled by pyrite and mineral matter. Representative photomicrographs of maceral of the Samarinda coals are shown in Figures 2 and 3, respectively.

4.3. Huminite/Vitrinite Reflectance. The vitrinite random reflectance (VRr) varies from 0.38 to 0.48 . The details of reflectance analysis have been summarized in Table 3 . Maximum vitrinite reflectance (300 counts on each sample) was measured on ulminite and gave a range of 0.3 to 0.5 , corresponding to lignite to subbituminous coal in the ASTM coal classification system.

4.4. Coal Microfacies. The petrographic composition of the coal has been studied in detail, in order to obtain a microfacies classification and to deduce palaeoenvironments during peat deposition. The percentages of the three maceral groups, huminite, inertinite, and liptinite, have been plotted in ternary diagrams (mineral-matter-free) for all coal seams (Figure 4) in order to provide the most basic information on coal deposition.

Based on these diagrams, most of the coals are with high content of huminite and low contents of inertinite and liptinite. The percentage of huminite is around $70 \mathrm{vol} . \%$ and greater than $70 \mathrm{vol} . \% \mathrm{mmf}$ and that of inertinite is usually around 10 or less than 10 vol. $\% \mathrm{mmf}$ and liptinite is less than $25 \mathrm{vol} \% \mathrm{mmf}$. Most of the studied coals fall into this type (Figure 4).

We have another two samples with huminite content greater than 75 vol.\% mmf, liptinite content less than 10 vol.\%, and an inertinite content between 10 and 30 vol.\%. Only two coal samples from Seam 16 and Seam 18 fall into this category.

Only one studied sample from Seam 10 describes coals with huminite contents lower than $50 \mathrm{vol} \%$, less than 30 vol.\% liptinite, and inertinite content between 20 and 20 vol. $\%$.

All of those coals are usually characterized by liptinite contents of less than $25 \% \mathrm{mmf}$ except Seam 10 which contains 


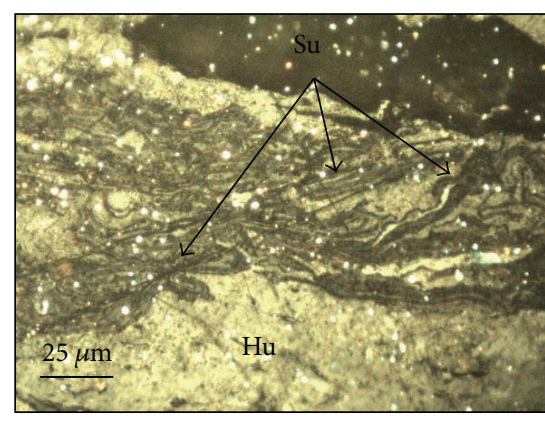

(a)

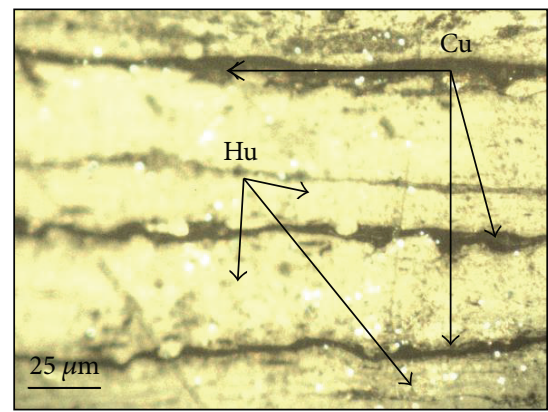

(c)

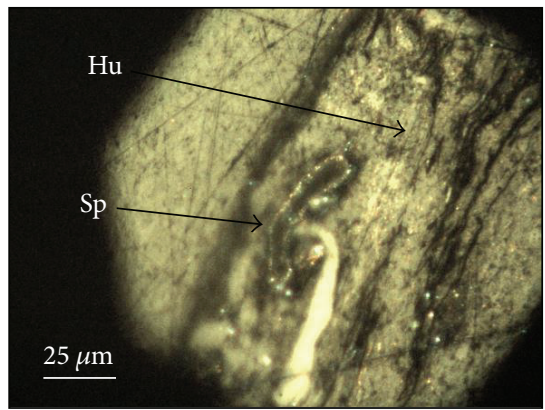

(e)

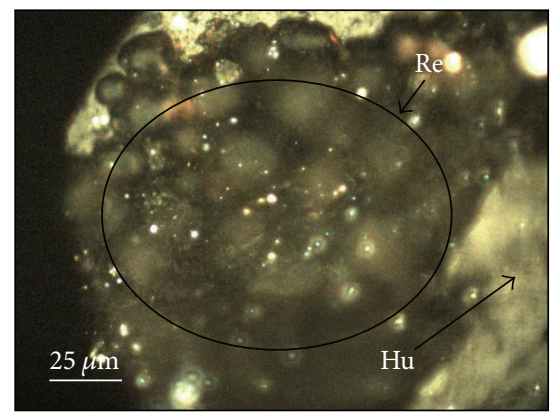

(g)

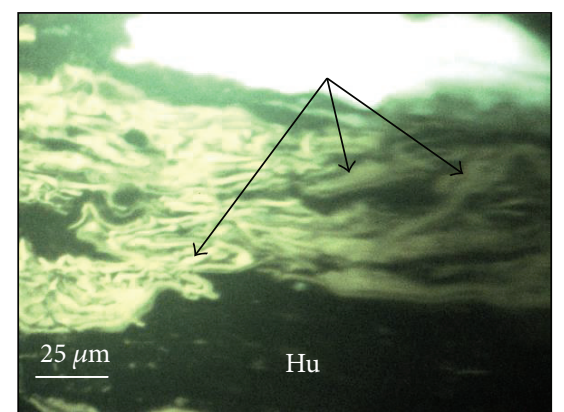

(b)

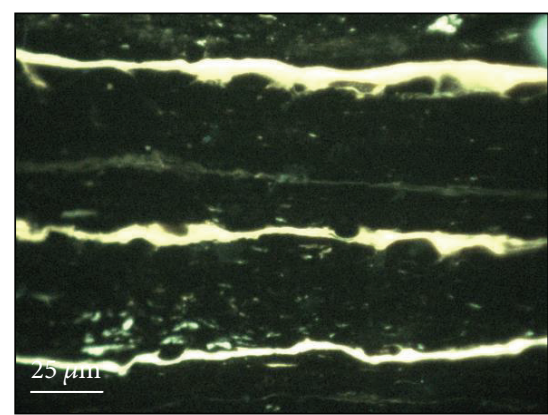

(d)

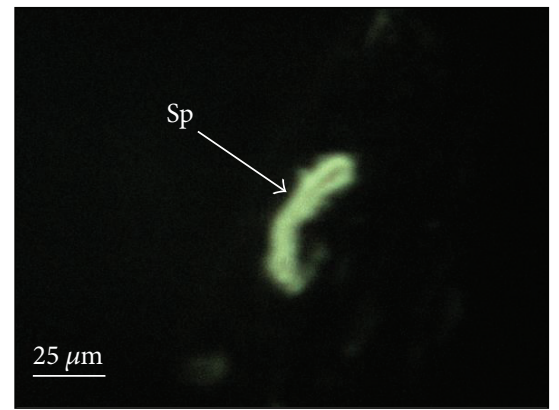

(f)

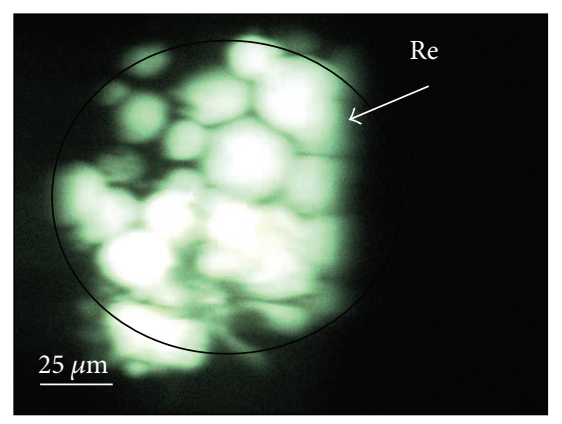

(h)

FIGURE 2: Representative photomicrographs of maceral of the Samarinda coals. (a) Humodetrinite associated with suberinite in coal, (a) reflected white light and (b) fluorescence mode as in (a), Sample 7. (c, d) Cutinite associated with humodetrinite, (c) in reflected light and (d) fluorescence mode in same view as (c), Sample 7. (e, f) Sporinite associated with humodetrinite (e) in reflectant white light and (f) fluorescence mode in same view as (e), Sample 16f. (g, h) Resinite associated with humodetrinite (g) in reflected white light and (h) in fluorescence mode, Sample 13. Su: suberinite, Hu: humodetrinite, Cu: cutinite, Sp: sporinite, and Re: resinite. 


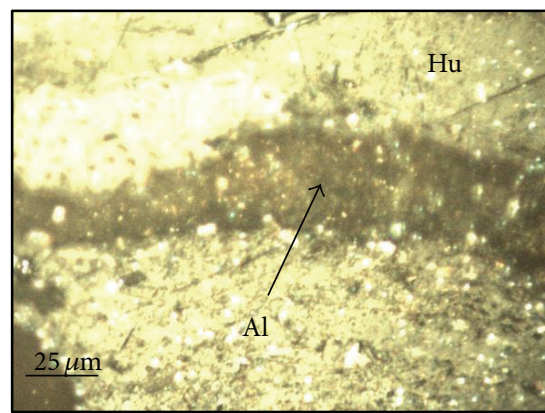

(a)

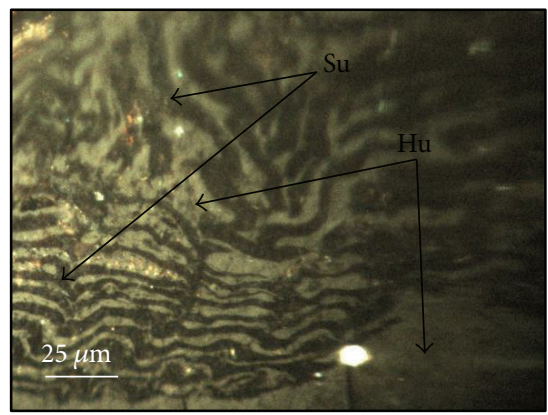

(c)

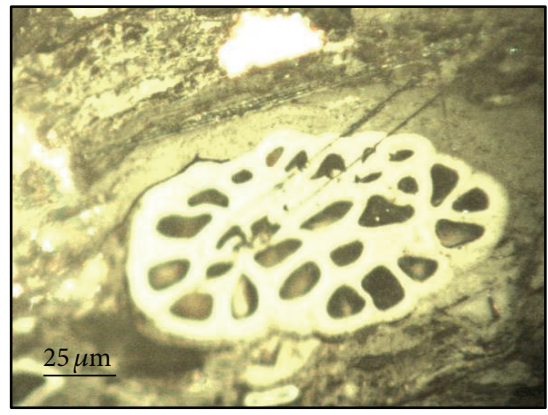

(e)

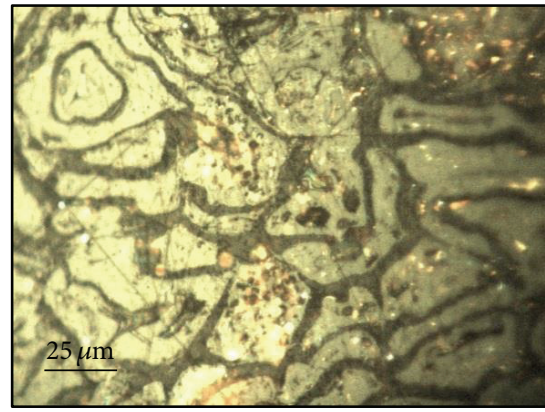

(g)

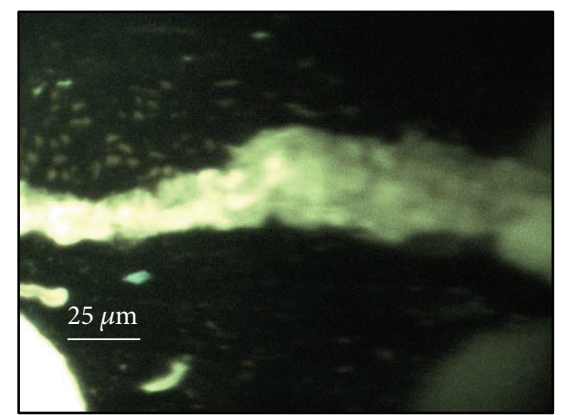

(b)

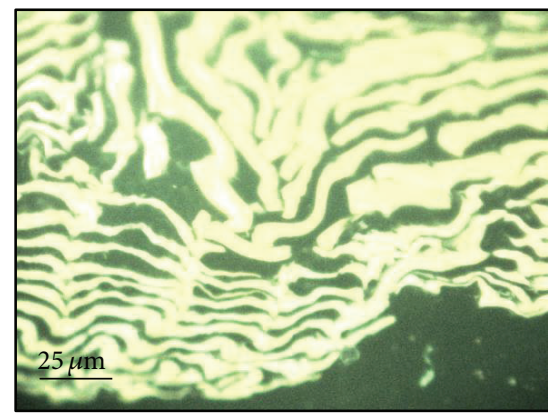

(d)

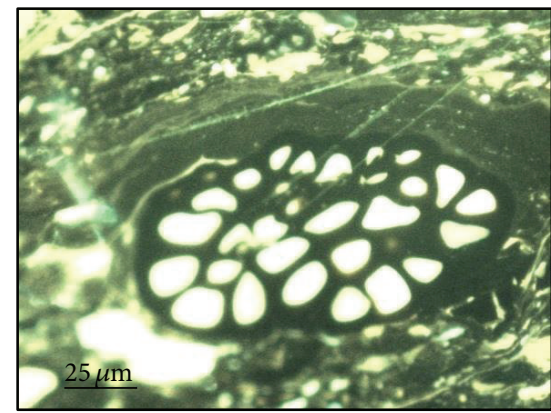

(f)

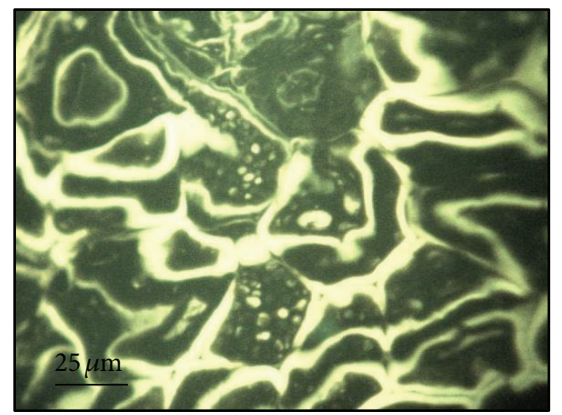

(h)

FIGURE 3: Representative photomicrographs of maceral of the Samfarinda coals. (a, b) Alginite associated with humodetrinite (a) in reflected white light and (b) fluorescence mode in same view as (a), Sample 7. (c, d) Suberinite associated with humodetrinite in coal, (c) reflected white light and (d) in fluorescence mode in same view as (c), Sample 10. (e) Funginite associated with humodetrinite groundmass in coal, (f) fluorescence mode in same view as (e), Sample 9. (g) Suberinite associated with humodetrinite groundmass in coal, Sample 9. (h) Same as for Figure (g), but in fluorescence mode. Hu: humodetrinite, Al: alginite, and Su: suberinite. 
TABLE 2: Petrographic data (maceral) analysis of coal samples from the studied area, $\mathrm{Ul}=$ ulminite, Den $=$ sensinite, Cor $=$ corpohuminite, $\mathrm{At}=$ attrinite, $\mathrm{Sp}=$ sporinite, $\mathrm{Cu}=$ cutinite, $\mathrm{Re}=$ resinite, $\mathrm{Al}=$ alginite, $\mathrm{Su}=$ suberinite, $\mathrm{Fu}=$ fusinite, $\mathrm{Sfu}=$ semifusinite, $\mathrm{Fun}=$ funginite, $\mathrm{In}$ $=$ inertodetrinite, $\mathrm{Py}=$ pyrite, and Other $=$ other minerals.

\begin{tabular}{|c|c|c|c|c|c|c|c|c|c|c|c|c|c|c|c|}
\hline Sample & Ul & Den & At & Cor & $\mathrm{Sp}$ & $\mathrm{Cu}$ & $\mathrm{Re}$ & $\mathrm{Al}$ & $\mathrm{Su}$ & $\mathrm{Fu}$ & Sfu & Fun & In & Py & Other \\
\hline 1 & 22.2 & 12.8 & 39.2 & 2.6 & 0.4 & 0.8 & 10 & 0.2 & 1.2 & 1.6 & 1.4 & 1.4 & 0.2 & 2 & 4 \\
\hline 2 & 14 & 8.6 & 43.6 & 1.4 & & 0.8 & & & 3.0 & 1.0 & 1.0 & 1 & 0.4 & 14.6 & 10.6 \\
\hline 3 & 4.2 & 39 & 52 & 9 & & & 0.6 & & & 1.4 & 1.6 & 2.2 & & & \\
\hline 4 & 1.4 & 9 & 54 & 5 & & 0.6 & 0.6 & & & 2.2 & 0.8 & 2.4 & 1 & 11.6 & 11.4 \\
\hline 5 & 1.8 & 1.8 & 64.4 & 2.6 & 19.6 & 1.4 & & & & 1.4 & 1.4 & 0.2 & 0.6 & 4.8 & \\
\hline 6 & 1 & 1 & 65.8 & 2.6 & 0.4 & 18.8 & 4.8 & & & 1.6 & 2.8 & & 0.8 & 0.4 & \\
\hline 7 & 6 & 0.4 & 56.2 & 11.6 & & 3.4 & 4 & & 6.0 & 0.8 & 1.2 & 7.4 & 0.4 & 2 & 0.6 \\
\hline 8 & 0.6 & 5.2 & 69.4 & 2.6 & & 10.2 & 3.8 & & & 1.4 & 4.6 & & & 1 & 1.2 \\
\hline 9 & 4.6 & 0.4 & 56.0 & 11.0 & & 5.6 & 8.4 & 1.0 & 5.0 & 0.8 & 0.2 & 2.6 & 0.4 & 3.4 & 0.6 \\
\hline 10 & 4.4 & 0.6 & 36.0 & & 0.6 & 2.8 & 13.6 & 1.0 & 7.4 & 5 & 0.6 & 10.0 & 6.6 & 4.0 & 7.4 \\
\hline 12 & 0.6 & 32.8 & 56 & 2.6 & & 3.4 & 1.2 & & & 2.4 & 1.0 & & & & \\
\hline 13 & 25.4 & 5.4 & 52.4 & 9.4 & & & 0.6 & & 4.4 & 1.0 & 1.0 & & & 0.4 & \\
\hline 14 & 1.6 & 31.2 & 57.4 & 2.6 & & 2 & 0.2 & & & 2.4 & 1.6 & & 1 & & \\
\hline 15 & 0.4 & 31.4 & 66.4 & & & & 0.2 & & & 1.6 & & & & & \\
\hline $16 a$ & & 9.6 & 75 & 7.4 & & 2.6 & 0.4 & & & 2 & 0.6 & & & 0.4 & 2.0 \\
\hline $16 \mathrm{~b}$ & 2 & 19.6 & 50.4 & 4.0 & & & 0.4 & & & & 0.6 & 1.6 & & 7.4 & 14.0 \\
\hline $16 c$ & 0.6 & 4.4 & 74.4 & 10.0 & & 0.6 & 1.4 & & & 3.0 & 0.6 & 3.6 & 0.4 & 0.4 & 0.6 \\
\hline $16 \mathrm{~d}$ & & & 94.6 & 1.0 & & & 0.6 & & & 0.8 & 1.4 & 1.6 & & & \\
\hline $16 \mathrm{e}$ & 0.5 & 2.6 & 78.4 & 1.4 & & 0.6 & 3.0 & & & 2.6 & 0.4 & 6.4 & 2.6 & 0.4 & 1.0 \\
\hline $16 f$ & 2.6 & 0.6 & 70.4 & 1.6 & 2.0 & & 1.4 & 0.4 & & 9.1 & 0.6 & 4.5 & 5.5 & 1.0 & 0.6 \\
\hline $16 \mathrm{~g}$ & 2 & 16.4 & 39.4 & 5.0 & & & & & & 6.6 & 2.0 & 3.4 & 0.6 & 2.6 & 22.0 \\
\hline 17 & 5.4 & 0.6 & 66.4 & 2.6 & & 1.2 & 2.0 & & 5.4 & & 3.4 & 6.0 & 6.0 & & 1.0 \\
\hline 18 & 1 & 1.8 & 64.5 & 2.1 & & 6.6 & 1.2 & & & 18.2 & 3.8 & 0.8 & & & \\
\hline 19 & 0.2 & 5 & 68.4 & 2 & 0.6 & 22.6 & & & & 0.2 & 0.6 & 0.4 & & & \\
\hline
\end{tabular}

less than $30 \%$. The petrological composition of coal seams is a key to understand the evolution of peat-forming depositional environments $[3,19-26]$ and many others. However, the reconstruction and interpretation of Samarinda coals cannot be solely based on coal facies change (I-III), as most coals were grouped as Group I.

In contrast, most of the Samarinda coals contain high content of huminite and low contents of inertinite and liptinite as huminite is around 70 vol.\% and greater than 70 vol.\% $\mathrm{mmf}$, inertinite is usually around 10 or less than $10 \mathrm{vol} \% \mathrm{mmf}$ and liptinite is less than $25 \mathrm{vol} \% \mathrm{mmf}$ (except Seam 10, Seam 17 and Seam 18 of facies II and III). Samarinda coals are represented by the humodetrinite-rich group. Humodetrinite is derived mainly from easily decomposable (lignin-poor and cellulose-rich) herbaceous plants and from angiospermous woods [22]. Large amounts of detrovitrinite (the counterpart of humodetrinite in high rank coal) indicate a high degree of cell-tissue destruction.

Some parts with high degree of plant tissue destruction are accompanied by relatively high inertinite content (e.g., see in Seam 10, Seam 17, and 18 of facies II and III). The samples of Seam 10, Seam 17, and Seam 18 have more higher inertinite content in comparison with other seams and contain abundant funginite bodies which are associated with humodetrinite, semifusinite, and inertodetrinite (see in Table 2).
The maceral analysis which is done on one seam (Seam 16) from base to top shows that the content of inertinite is relatively higher from the base to the top of the seam (Figure 5). The top section of a domed peat can also be characterized by inertinite, mainly fusinite. The petrographic analysis conducted on domed mires in Kalimantan, Indonesia by Demchuck and Moore [27] or Dehmer, 1993 [28] has shown significant increases in oxidized plant material near the top of the peat. Moore et al., 1996 [29], who also examined peat deposit from Kalimantan, found that the high concentration of oxidized material can be generated through fungal mechanism in response to an abnormally fluctuating water table. This mechanism can lead to the formation of inertinite in coal as the peat deposit dies and gets decomposed.

4.5. Microlithotype Analysis. Total vitrite, vitrinertite, clarite, and duroclarite are also high due to the high content of vitrinite (mmf basis), while total inertite ranges from $1 \%$ to $2.5 \%$ ( $\mathrm{mmf}$ basis) and there is no liptite in these coals. The Petrographic (microlithotype) analysis of coal samples from the studied stratigraphic section and their microlithotype content (volume \%) are shown in Table 4 and Figure 6.

The microlithotype is dominated by vitrite, vitrinertite, and duroclarite. Liptite is absent and inertite is rarely seen. Duroclarite is the most dominant Trimacerite in these coals. 
TABLE 3: Vitrinite/huminite reflectance of Samarinda coal.

\begin{tabular}{lcc}
\hline Seam & $\operatorname{Rr}(\%)$ & Mean Rr value \\
\hline Seam 1 & $0.34-0.43$ & 0.39 \\
Seam 2 & $0.38-0.46$ & 0.42 \\
Seam 3 & $0.34-0.38$ & 0.36 \\
Seam 4 & $0.25-0.34$ & 0.30 \\
Seam 5 & $0.32-0.43$ & 0.38 \\
Seam 6 & $0.30-0.39$ & 0.35 \\
Seam 7 & $0.43-0.48$ & 0.45 \\
Seam 8 & $0.26-0.34$ & 0.30 \\
Seam 9 & $0.35-0.47$ & 0.44 \\
Seam 10 & $0.37-0.43$ & 0.40 \\
Seam 12 & $0.22-0.39$ & 0.31 \\
Seam 13 & $0.40-0.47$ & 0.44 \\
Seam 14 & $0.41-0.44$ & 0.43 \\
Seam 15 & $0.40-0.46$ & 0.43 \\
Seam 17 & $0.31-0.41$ & 0.36 \\
Seam 18 & $0.36-0.45$ & 0.41 \\
Seam 19 & $0.39-0.48$ & 0.44 \\
Seam 16a & $0.42-0.35$ & 0.38 \\
Seam 16b & $0.31-0.42$ & 0.38 \\
Seam 16c & $0.33-0.45$ & 0.38 \\
Seam 16d & $0.37-0.46$ & 0.40 \\
Seam 16e & $0.27-0.35$ & 0.31 \\
Seam 16f & $0.28-0.39$ & 0.33 \\
Seam 16g & $0.35-0.42$ & 0.37 \\
\hline Se: Rr & &
\end{tabular}

Note: $\mathrm{Rr}=$ Random reflectance.

Clarodurite is less abundant in some seams and vitrinertoliptite is very rare, (mmf basis). The details of the various microlithotypes are summarized in Table 4 and Figure 6, respectively.

Vitrite shows the most homogeneous nature under a microscope. Telinite, telovitrinite, and collinite occur in bands more than $50 \mu$ thick. It comprises two maceralstelinite and collinite; two different types of vitrite can be distinguished, one without visible structure in reflected light and the other showing structure.

It also occurs in hand specimens in the form of bright layers only a few millimeters thick (less than $10 \mathrm{~mm}$ ) and of limited lateral extent. Inertite is dominated by fusinite, semifusinite, funginite, and inertodetrinite.

Vitrinertite occur the most percentage among bimacerites. Most are rich in vitrinite (vitrinertite V) and sometime vitrinertite I also occurs in lesser amount most frequently. Most of the clarites are liptinite-poor clarites. Most are cutinite-clarite. The liptinite content of clarites does not exceed 10 to $20 \%$. Vitrinite portion is attrinite, ulminite, densinite, and corpohuminite. Most of the liptinite portion is cutinite and sometimes resinite is found in some seams. Durite is very rarely occurred in all coal seams.

Duoclarite occurs 20-60 percent in some seams. Vitenerolipnite also rarely occurred (less than $2 \%$ ) in one seam and (less than $0.5 \%$ ) in two seams. Clarodurite occurs in $16.5 \%$ in one seam, $6-8.5 \%$ in two seams, and less than $2 \%$ in all seams.

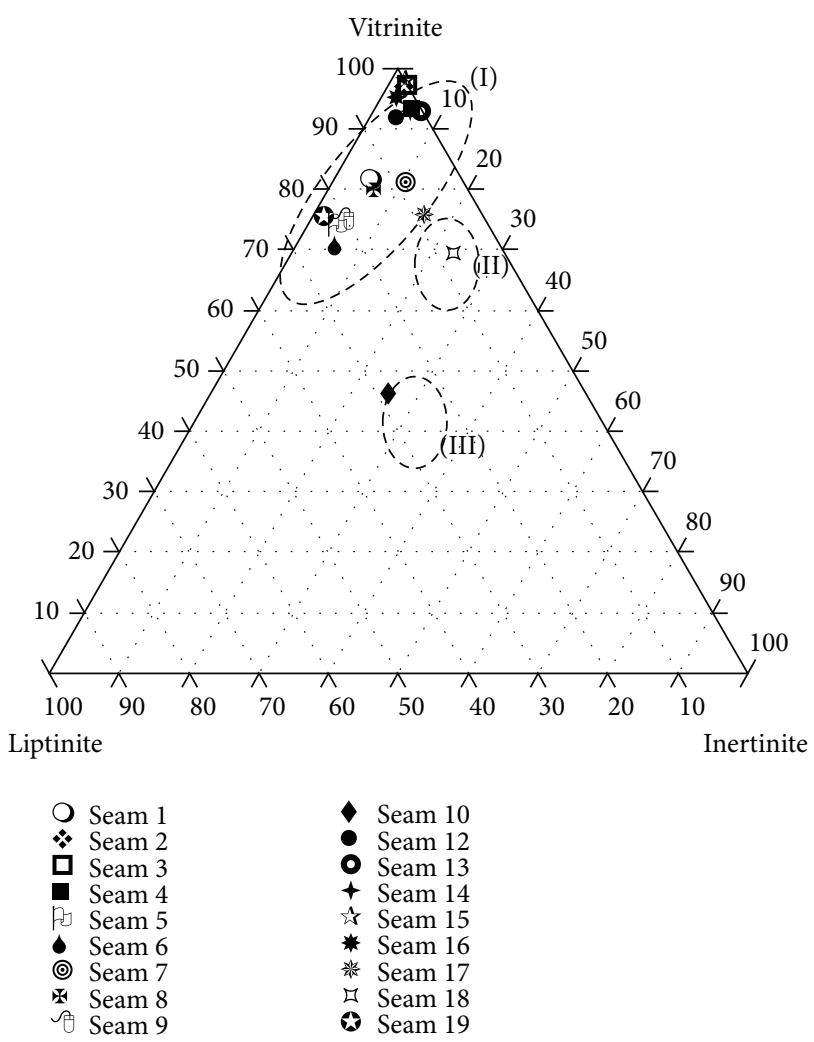

FIGURE 4: Facies of Samarinda coals based on their maceral group composition ( $\mathrm{mmf}$ basis).

4.5.1. Depositional Environment. Depositional environments have a significant role to play in deciphering the composition and preservation of peat and coals. The maceral compositions, obtained through petrographic analysis, necessarily characterize the paleomires, since they depend on plant as well as the environment. Several researchers [20, 30-35] have correlated the petrographic components of coal with the paleoecological conditions. Teichmüller, 1989 [22] showed that depositional environment can be assessed through the presence or absence of certain macerals and, thus, maceral indices are useful in order to depict some genetic features of coals.

When microlithotype composition of the coals are plotted in a facies diagram (Table 5 and Figure 7) proposed by Marchioni, 1980 [16], only three seams occur in the forest terrestrial moor and the others are in the wet forest swamp of telmatic zone.

Another facies model which is depositional milieus of peat formation and related microlithotypes of Australian hard coals from Smyth, 1984 [17], takes into account the microlithotype composition of these coals.

When the microlithotype composition of all seams (Seams 1 to 19) of the studied area are plotted in the diagram, it indicates that most of the seams are in fluvial, four seams (Seam 1, Seam 4, Seam 16, and Seam 18) are in brackish water, and two seams (Seam 2 and Seam 10) are in upper deltaic fields (Figure 8(a)). It is shown that only fluvial environment (except Sample 16e) when plotted by the Seam 16 which 
TABLE 4: Petrographic data: (microlithotype) analysis of coal samples from the studied area, V: vitrite, L: liptite, I: inertite, VI: vitrinertite, C: clarite, D: durite, DC: duroclarite, VL: vitrinertoliptite, CD: clarodurite.

\begin{tabular}{|c|c|c|c|c|c|c|c|c|c|}
\hline Seam & $\mathrm{V}$ & $\mathrm{L}$ & I & VI & $\mathrm{C}$ & $\mathrm{D}$ & $\mathrm{DC}$ & $\mathrm{VL}$ & $\mathrm{CD}$ \\
\hline Seam 1 & 39 & 0 & 0 & 34.5 & 5 & 0 & 20.5 & 0.5 & 0.5 \\
\hline Seam 2 & 7.5 & 0 & 0 & 30.5 & 15 & 0 & 36 & 2 & 9 \\
\hline Seam 3 & 96 & 0 & 0 & 3.5 & 0.5 & 0 & 0 & 0 & 0 \\
\hline Seam 4 & 44.5 & 0 & 2.5 & 13.5 & 0 & 0 & 23 & 0 & 16.5 \\
\hline Seam 5 & 32.5 & 0 & 0 & 9 & 44 & 0 & 14 & 0 & 0.5 \\
\hline Seam 6 & 61 & 0 & 0 & 9.5 & 27.5 & 0.5 & 1.5 & 0 & 0 \\
\hline Seam 7 & 65.5 & 0 & 0 & 6.5 & 21 & 0 & 7 & 0 & 0 \\
\hline Seam 8 & 61 & 0 & 0 & 8.5 & 27.5 & 0 & 3 & 0 & 0 \\
\hline Seam 9 & 68 & 0 & 0 & 5 & 24 & 0.5 & 2 & 0 & 0.5 \\
\hline Seam 10 & 19 & 0 & 0 & 9.5 & 9.5 & 0 & 59.5 & 0 & 2.5 \\
\hline Seam 12 & 26.5 & 0 & 0 & 49 & 17.5 & 0 & 5.5 & 0 & 1.5 \\
\hline Seam 13 & 55 & 0 & 0 & 17 & 16.5 & 0 & 10.5 & 0 & 1 \\
\hline Seam 14 & 53.5 & 0 & 0 & 31.5 & 7 & 0 & 8 & 0 & 0 \\
\hline Seam 15 & 98.5 & 0 & 0 & 1.5 & 0 & 0 & 0 & 0 & 0 \\
\hline Seam 16 & 31 & 0 & 1.5 & 23 & 18 & 0 & 20 & 0 & 6.5 \\
\hline Seam 17 & 51 & 0 & 0 & 10 & 27 & 0.5 & 10.5 & 0.5 & 0.5 \\
\hline Seam 18 & 30.5 & 0 & 1 & 53 & 2.5 & 0 & 12 & 0 & 1 \\
\hline Seam 19 & 35.5 & 0 & 0 & 0.5 & 54 & 0 & 9 & 0 & 1 \\
\hline
\end{tabular}

TABLE 5: Petrographic data: (microlithotype group) analysis of coal samples from the studied area, Group A: sporoclarite + duroclarite + vitrinertoliptite; Group B: fusitoclarite + vitrinertite-I; Group C: clarite-V + vitrite + cuticoclarite; Group D: clarodurite + durite + macrolite + carbominerite.

\begin{tabular}{|c|c|c|c|c|}
\hline Seam number & Group A & Group B & Group C & Group D \\
\hline Seam 1 & 6.15 & 44.13 & 49.16 & 0.6 \\
\hline Seam 2 & 18.1 & 48.4 & 23.93 & 9.5 \\
\hline Seam 3 & 0.5 & 3.96 & 95.5 & 0.4 \\
\hline Seam 4 & 0 & 18.2 & 59.73 & 22.15 \\
\hline Seam 5 & 25.29 & 30.46 & 43.97 & 0.29 \\
\hline Seam 6 & 17.9 & 24.1 & 57.65 & 0.3 \\
\hline Seam 7 & 15.56 & 20.37 & 64 & 0 \\
\hline Seam 8 & 18.1 & 23.68 & 58.22 & 0 \\
\hline Seam 9 & 16.4 & 19.86 & 63.01 & 0.68 \\
\hline Seam 10 & 15.97 & 31.93 & 47.9 & 4.2 \\
\hline Seam 12 & 13.51 & 51.35 & 33.98 & 1.16 \\
\hline Seam 13 & 13.47 & 27.35 & 58.37 & 0.8 \\
\hline Seam 14 & 6.6 & 36.32 & 57.08 & 0 \\
\hline Seam 15 & 0 & 1.5 & 98.5 & 0 \\
\hline Seam 16 & 15.72 & 35.81 & 42.79 & 5.68 \\
\hline Seam 17 & 19.16 & 25.78 & 54.36 & 0.7 \\
\hline Seam 18 & 2.7 & 60.33 & 35.87 & 1.1 \\
\hline Seam 19 & 27.14 & 27.39 & 49.97 & 0.5 \\
\hline
\end{tabular}

represents all the different lithotypes from roof and floor of that seam (Figure 8(b)).

Based on maceral composition and microfacies analysis, Samarinda coals are rich in huminite and poor in liptinite and internite. Microlithotype analysis also shows that most of the coals have high content of vitrite and low content of clarite, durite, inertinite, and intermediates (trimacerite). Facies diagram proposed by Marchioni, 1980 indicated that terrestrial into telmatic condition of peat formation with vegetation characteristics of forest moor type. The four seams (Seam 1, Seam 2, Seam 4, and Seam 10) contain high duroclarite (vitrinite-rich and liptinite-poor) and Seam 18 has high vitrinertite (vitrinite-rich) content which lead to produce mixed results (Table 4 and Figure 6). The facies diagram proposed by Smyth only focused on the composition of microlithotypes and may lead to mixed result when using the 


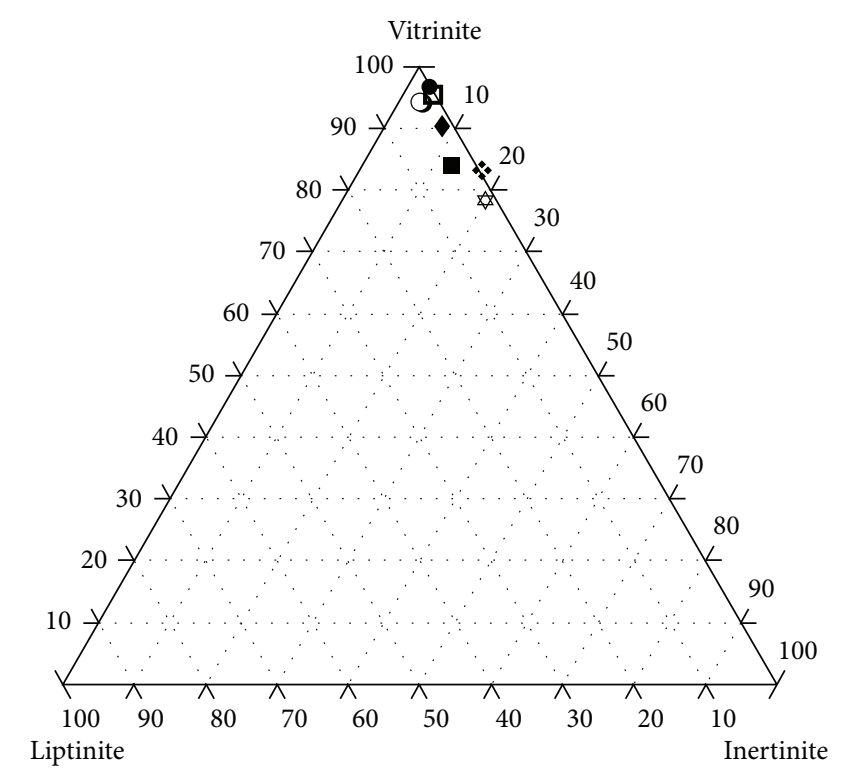

Seam base
$\mid \begin{aligned} & O 16 \mathrm{a} \\ & \bullet 16 \mathrm{~b} \\ & \square 16 \mathrm{c} \\ & \square 16 \mathrm{~d} \\ & \square 16 \mathrm{e} \\ & \star 16 \mathrm{f} \\ & \star 16 \mathrm{~g}\end{aligned}$

Seam top

Figure 5: Facies of Samarinda coals (representative Seam 16) based on their maceral group composition (mmf basis). Note that the content of inertinite is relatively higher than the top section.

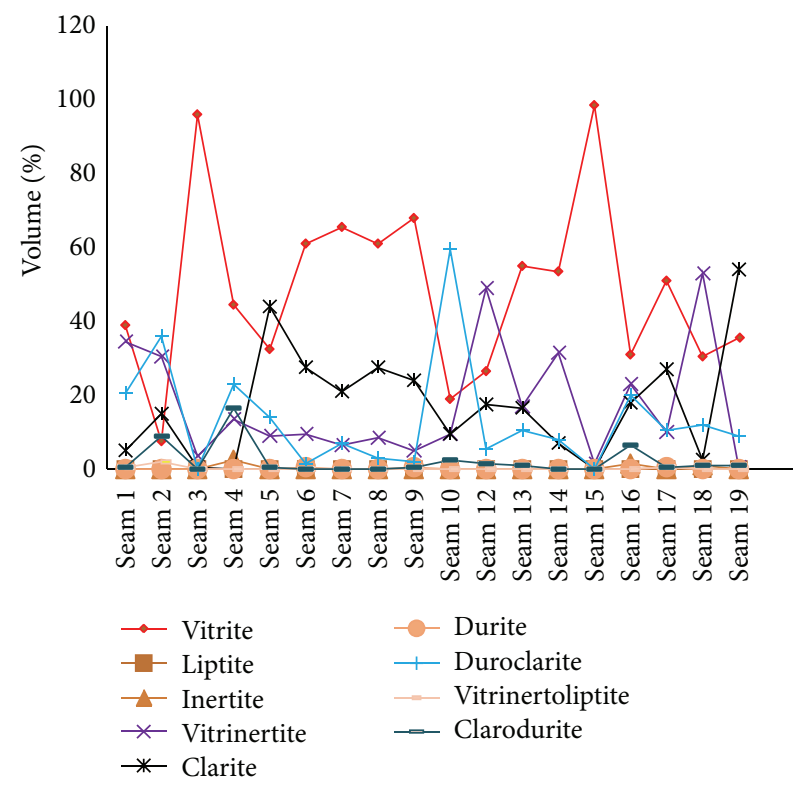

FIGURE 6: Graphs showing the volume percentage of microlithotype in each coal seam in the studied area.
(B)

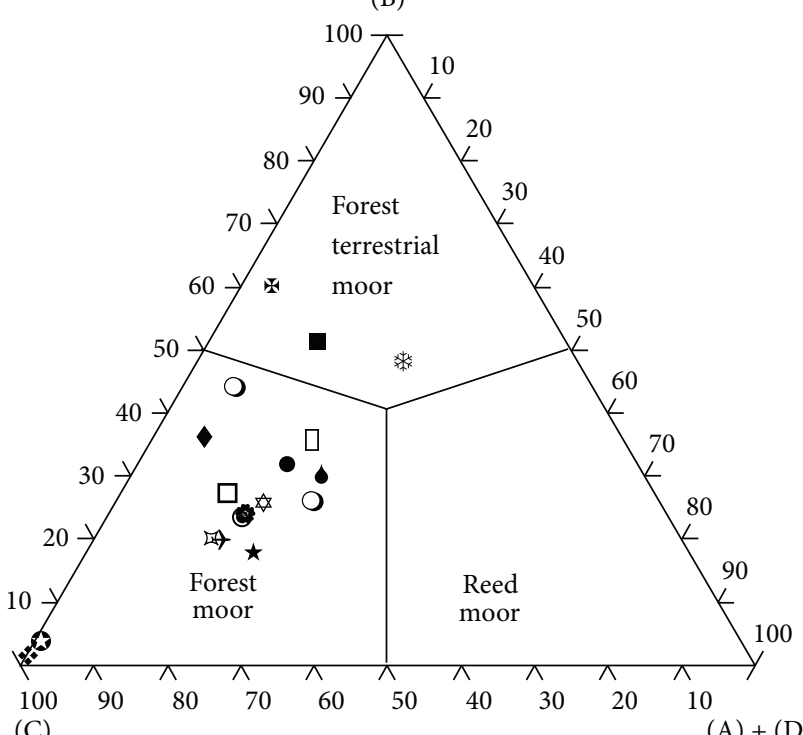

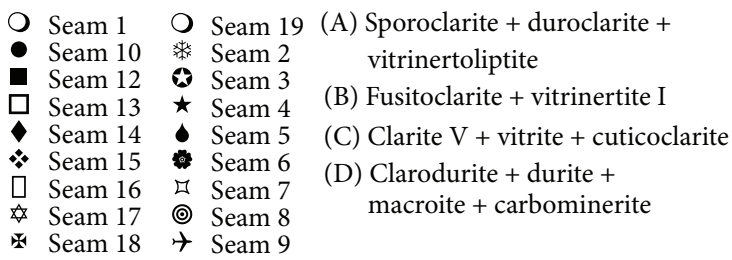

FIGURE 7: Microlithotype composition of coals of the studied area plotted on a facies diagram proposed by Marchioni, 1980 [16].

coals contain high duoclarite-V (vitrinite-rich and liptinitepoor) and vitrinertite-V (vitrinite-rich).

According to Stach, 1982 [15], (in Stach's Text Book of Coal Petrology), the vitrinite rich trimacerites, especially the liptinite-poor duoclarite, are most probably deposited in forest swamps and trimacerite with high inertinite content may form under relatively dry depositional conditions or by an alternation of high and low ground water table, due to temporary drainage of the peat surface. Therefore, if the same environment of macerals which prevailed relatively dried condition could be misleading to different environment due to the high content of vitrinertite. Furthermore, brackish water swamps have considerably less organic material and it is not possible to consider Samarinda coal with high huminite as brackish water coal. Therefore, Interpretation of coal depositional milieus of peat formation based on microlithotype composition alone as suggested by Figure 6 is not fitted with the coals which contain high vitrinite.

Mineral matter has also been used to relate the dry and wet conditions of the peat deposition and the rate of subsidence of the basin. Though the mineral matter concentration is low (less than 6 vol.\% except around $25 \mathrm{vol} . \%$ or less than 25 vol.\% in Seams 2, 4, and 10) in the Samarinda coals, yet one model developed by M. P. Singh and P. K. Singh, 1996 [18], has been used to describe the evolution of these coals in relation to the mineral matter content. The ternary plot (Figure 9) supports the earlier contention and indicates 


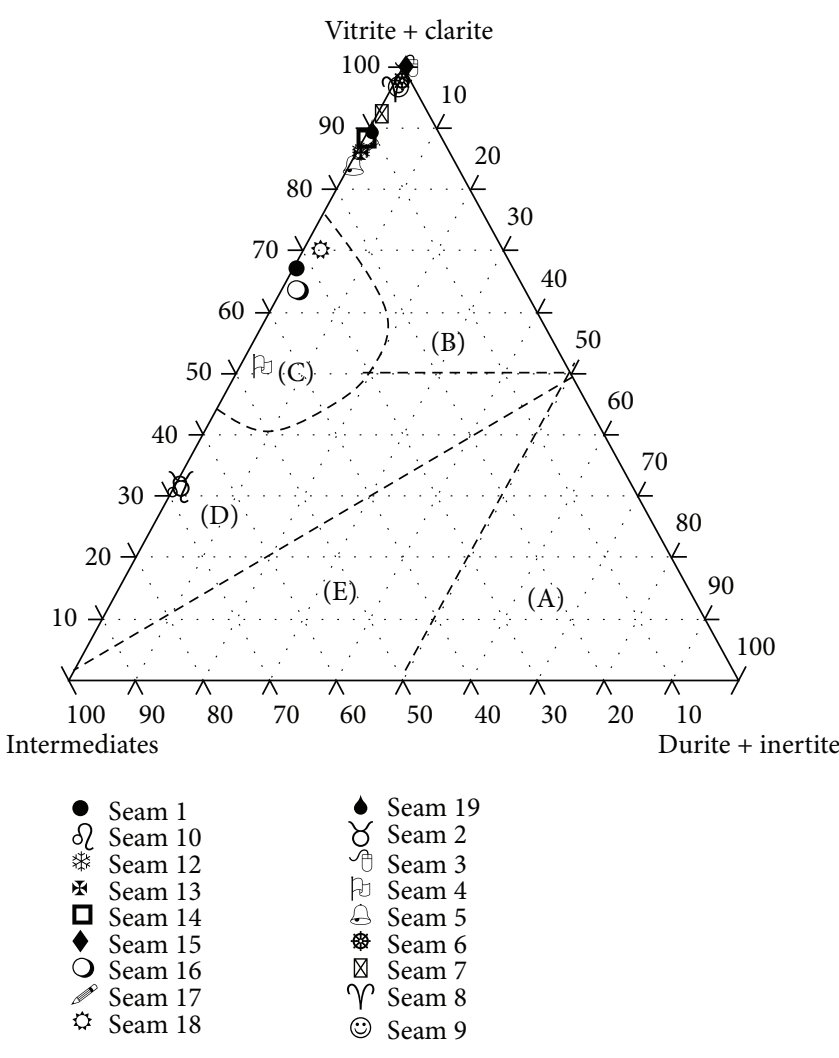

(a)

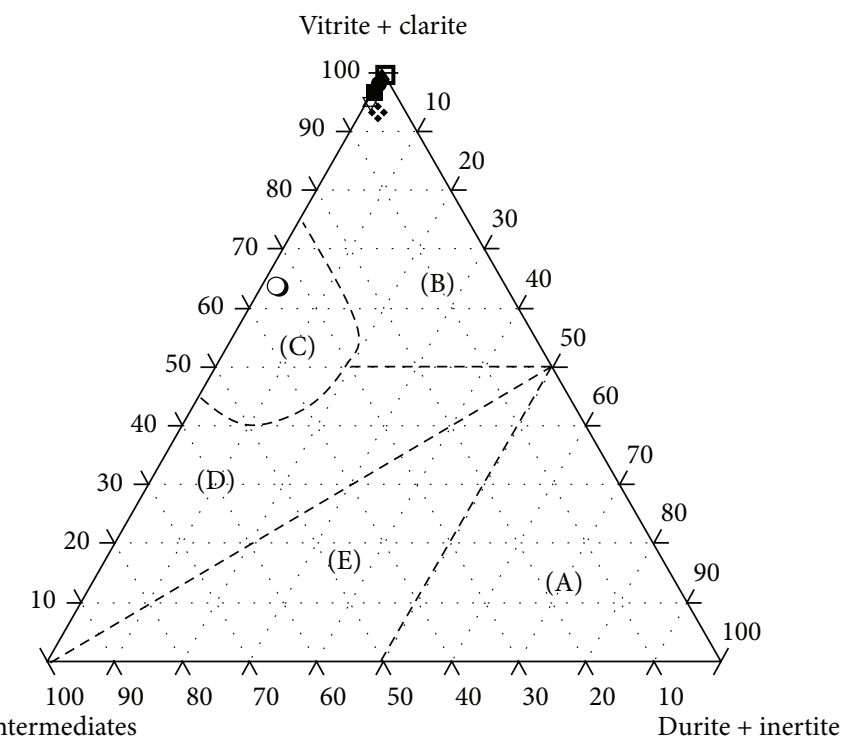

(b)

FIGURE 8: Depositional milieus of peat formation of the study area plotted on a diagram proposed by Smyth, 1984 [17]; (a) microlithotypes of the studied area; (b) microlithotypes of representative Seam 16. Note the following: A: lacustrine, B: fluvial, C: brackish water, D: upper deltaic, and E: lower deltaic environments.

that these coals evolved under alternate oxic to anoxic moor condition with intermittent moderate to high flooding. This contention gets support from the evidence of fluctuation in the eustatic sea level during the entire Miocene period which is well documented by Haq et al.,1987 [36].

4.6. Tissue Preservation and Gelification Index. Diessel, 1986 [19] developed the gelification index (GI) and tissue preservation index (TPI) based on coal facies analysis on Permian coals in Australia, in order to establish a correlation between coal facies indicators and the environment of coal formation. GI is the ratio of gelified and fusinitised macerals whereas TPI emphasises the degree of tissue preservation versus destruction. TPI can be used as a measure of the degree of humification and GI is related to the continuity in moisture availability.
Lamberson et al., 1991 [23] made some modifications on GI and stated that an alternative way to view this index is the inverse of an oxidation index. Those indices were also used and modified to define the depositional environment of coals from different areas and ages (e.g., $[26,37,38]$ and many others). Based on the modification by Lamberson et al., 1991 [23], Amijaya and Littke, 2005 [39], modified for their studied Tertiary Tanjung Enim low-rank coal from Sumatra as telovitrinite macerals were substituted by their precursors (humotelinite), detrovitrinite by humodetrinite, and gelovitrinite by humocollinite. Fusinite, semifusinite, and funginite are grouped as teloinertinite, whereas macrinite and secretinite are grouped as geloinertinite. The modified formulas used are as follows:

$$
\begin{gathered}
\text { TPI }=\frac{\text { humotelinite }+ \text { teloinertinite }}{\text { humodetrinite }+ \text { humocollinite }+ \text { inertodetrinite }+ \text { gelo-inertinite }} \\
\text { GI }=\frac{\text { huminite }+ \text { gelo-inertinite }}{\text { inertinite (exclusive of macrinite and secretinite) }} .
\end{gathered}
$$

The present study used the modification formula of Amijaya and Littke as Samarinda coals are also low rank and their age is Middle Miocene. Coal facies diagrams for Samarinda coals are illustrated in Figures 8(a) and 8(b). 
Almost all the analyzed coals have a low TPI and high GI. The TPI versus GI plot (Figure 10) suggests that Samarinda coals evolved under limnic environment in the limited influx clastic marsh field.

4.7. Vegetation and Groundwater Index. Another method of analysis to evaluate coal depositional environment was proposed by Calder et al., 1991 [3], for Westphalian coal of Nova Scotia. They suggested a mire paleoenvironment diagram based on a groundwater influence index (GWI) and a vegetation index (VI) expressed as maceral ratios.
The GWI evaluates the intensity of rheotrophic conditions as a ratio of strongly gelified to weakly gelified tissues. The VI is a measure of vegetation type by contrasting the macerals of forest affinity with those of herbaceous and marginal aquatic affinity. Later on, those indices were adapted to assess the development of paleomires in different areas, for example $[38,40]$.

Modification was also necessary on Calder's ratios for the purpose of this study. The macerals/submacerals of hard coals were substituted by their low-rank coal counterparts [3]. The ratios are expressed as

$$
\begin{aligned}
& \text { GWI }=\frac{\text { gelinite }+ \text { corpogelinite }+ \text { mineral matter }}{\text { texo-ulminite }+ \text { E-ulminite }+ \text { attrinite }+ \text { densinite }+ \text { desmocollinite }+ \text { tellocollinite }} \\
& \mathrm{VI}=\frac{\text { texo-ulminite }+(\mathrm{eu}) \text { ulminite }+ \text { fusinite }+ \text { semifusinite }+ \text { suberinite }+ \text { resinite }}{\text { attrinite }+ \text { densinite }+ \text { inertodetrinite }+ \text { alginate }+ \text { liptodetrinite }+ \text { sporinite }+ \text { cutinite }} .
\end{aligned}
$$

Plots of Samarinda coals are shown in Figures 11(a) and 11(b). Most of the studied coals lie in the area where both vegetation index and groundwater index values are low. Calder et al., 1991 [3], proposed the GWI value of 3 as the border, above which the ecosystem is considered to be predominantly limnotelmatic. Most of the studied coal samples have GWI values of less than 0.5 , indicating that the paleoenvironment was dominated by limnic conditions. These low values indicate that groundwater ceased to be influential and the mire became solely rain-fed (ombrotrophic).

The interpretation scheme used in Seam 16 Figure 11(b) suggests that the paleopeat environment shifted mesotrophic to ombrotrophic first and then mesotrophic again. Almost all the studied coal samples have low VI values of less than 1 and most plot in the marginal aquatic/herbaceous vegetation field in the diagram. This fact supports the view that forest vegetation was only a minor precursor of these coal samples according to facies diagram proposed by Calder et al., 1991 [3].

\section{Discussion}

According to the results from the maceral ratio interpretation methods proposed by Diessel, 1986 [19], and Calder et.al., 1991 [3], Samarinda coals evolved under limnic environment in the limited influx clastic marsh and the marginal aquatic/herbaceous vegetation.

The term "marsh" is used to identify peatforming areas which were predominantly covered by herbaceous plants [5, 23, 41]. Climate, depositional environment, mire type, and vegetation type dictate peat composition. Tropical lowland peat deposits are often dominated by trees and shrubs according to Polak, 1933 [42], 1975 [43]; Merton, 1962 [44]; Anderson, 1976 [45], 1983 [46]; Morley, 1982 [47]; Frim, 1997 [48]; Giesen, 1998 [49]; Phillips and Bustin, 1998 [50]; Wüst and Bustin, 1999 [51]. The predominantly forested tropical peat-forming environments result in wood-rich peat deposits, unlike most temperate peat deposits, which are often dominated by shrubs, grasses, and bryophytes [52]. Tropical peats are therefore often rich in lignin with only small amounts of hemicellulose, cellulose, protein, and watersoluble compounds $[43,53,54]$, which are lost due to vigorous microbial activity. It is commonly thought that woody peats generally result in bright, vitrain-rich coal [14, page 37] and peat derived from bryophytes or Cyperaceae produce dull coal. Well-humified, inertinite-rich, or gelified organic deposits are thought to result dull coals [14, page 292].

Many resent studies showed that peats from Malaysia, Indonesia, Irian Jaya, or Thailand have large amounts of woody material (branches, roots, and stumps with bark) and variable quantities of sapric, amorphous matrix. The matrix contains residues and fragments of fungi, bacteria, plankton, sponges, fibres, leaves, roots, cuticles, epidermis, trichomes, spores, and pollen.

Based on the study of recent tropical peat in Indonesia and Malaysia, they are ombrotrophic composed chiefly of wood from swamp forest vegetation and the peat type is hemic to sapric [24, 55, 56]. Moore and Ferm, 1992 [57], studied coal from Southeastern Kalimantan and stated that Miocene lignite have accumulated from a woody angiosperm flora. Singh et.al., 2010 [58], studied coal from the Lati Formation, Tarakan basin, East Kalimantan, Indonesia, and found that these coals have originated under telmatic condition and there was predominance of wood derived tissues.

During the Miocene, Indonesia was located in a tropical area $[59,60]$. It can be assumed that the climate during Miocene peat deposition was similar to the modern climate in SE Asia today. In general, peat deposits in Indonesia are situated in a zone of annual rainfall exceeding $2.5 \mathrm{~m}$. Even minimum rainfall usually exceeds evapotranspiration in the peatlands leading to ever wet conditions. Only during exceptional long, drought periods that the peat may dry out and sometimes becomes inflammable $[61,62]$.

The peat-forming vegetation probably has not much changed since the Miocene [27, 47]. A vegetation model of tropical peat deposits is described by $[45,62]$ as the succession 


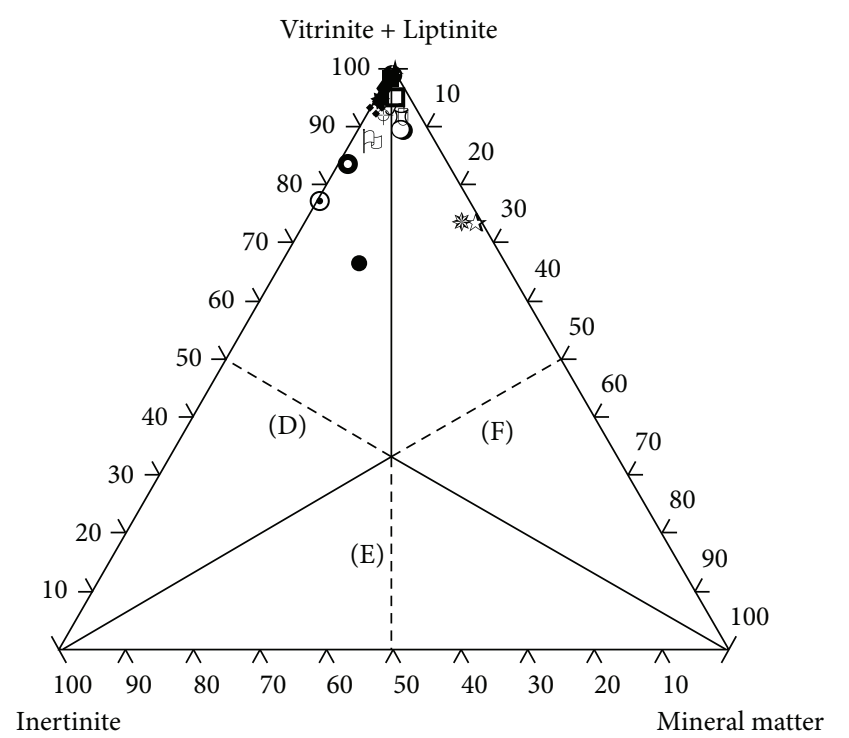

FIgURE 9: Depositional conditions of Samarinda coals plotting based on maceral and mineral matter content diagram of M. P. Singh and P. K. Singh, 1996 [18].

is characterized by a change from mixed swamp forest consisting of large trees to thin Shorea albida trees referred to as "pole forest" and then to an "open savanna woodland" vegetation of Pandanus, small shrubs, and thin trees. Some vegetational successions that show a development from topogenous to ombrogenous peat can also be observed within the raised peat deposits in Kalimantan, Indonesia [28, 55, 63].

The high GI, that is, the high huminite/inertinite ratio, is also known to be typical of recent and ancient Indonesian peat and coal deposits [63-65]. The types of liptinite submacerals in the Samarinda coals are stable liptinite macerals (including, suberinite, sporinite, and resinite) as well as dispersed residues of fusinite and semifusinite (in form of inertodetrinite).

Dehmer, 1995 [63], studied petrological and organic geochemical investigation of recent peats with known environments of deposition. They calculated for the peat samples from tropical and subtropical regions to see how maceral indices would fare in interpreting their known environments of deposition. Their results have proved to be generally unsuccessful as the herbaceous and woody peats did not always give the predicted high humodetrinite and humotelinite compositions, respectively. Their study showed that care must be taken when using maceral indices as the sole method of interpreting coal facies.

Wüst et.al., 2001 [24], compared maceral ratios from tropical peatlands with assumptions from coal studies and

found that in the modern peat deposits from the Tasek Bera basin, Malaysia, divergent petrographic results occur in similar depositional environment. He also stated that from the time of peat deposition, peat is subject to considerable alteration and during subsequence diagenesis, preservation of structured and strongly altered materials, such as inertinite, gelified material, or funginite, is favoured and results in biased coal maceral compositions because maceral indices in modern peat studies are of little utility in the reconstruction of paleoenvironmental settings. It follows that coal maceral indices should not be utilized in the future to interpret paleodepositional environment of coals.

While working on the coals of South Sumatra basin of Indonesia, Amijaya and Littke, 2005 [39] used TPI and GI indices, but they feel that the related interpretation scheme does not fit to these coals as the indices were initially developed for the Permian coals of Australia. The present study of Samarinda coal advocates the same with Amijaya and Littke, 2005 [39].

Therefore, the paleoenvironment of Samarinda coals did not evolve under limnic environment in the limited influx clastic marsh environment and marginal aquatic/herbaceous vegetation as illustrated in Figures 9(a) and 9(b). Some limitations of using the TPI and GI diagram have already noted, for example, by Crosdale, 1993 [66], Dehmer, 1995 [63], Nas and Pujobroto, 2000 [65], Wüst et.al., 2001 [24], Scott, 2002 [67], Moore and Shearer, 2003 [68], and Amijaya and Littke, 2005 [39]. The GWI and VI diagram of Calder et.al., 1991 [3], still provided some interesting insight with respect to the ratio of herbaceous to woody material and the intensity of rheotrophic conditions as a ratio of strongly gelified to weakly gelified tissues.

The highly degraded tertiary tropical coals deposited in wet forest swamp and compose of high content of detrohuminite. The higher content of detrovitrinite in these tropical coals may lead to the misinterpretation of paleoenvironment as limnic and marginal/aquatic herbaceous vegetation. The fields for the marginal aquatic/herbaceous and inundated marsh should be removed from this diagram in order to adjust for the highly degraded tertiary tropical coals which were deposited in the forest swamp environment. Therefore, some modification on GWI and VI diagram of Calder et al., 1991 [3], is made for the Samarinda coals as in Figure 12 in order to implement the peat environment. Therefore, Samarinda coals plot in the highly degraded woody forest field.

\section{Conclusion}

The coals in the Samarinda area are of low rank and contain high content of huminite and low contents of inertinite and liptinite. The mineral matter content is relatively low except for Seam 1, Seam 2, Seam 4, and Seam 10 which contain high mineral matter. Samarinda coals are represented by the highly degraded humodetrinite-rich group. Samarinda coals deposited from terrestrial into telmatic condition of peat formation with vegetation characteristics of highly degraded woody forest type evolved under alternate oxic to anoxic 


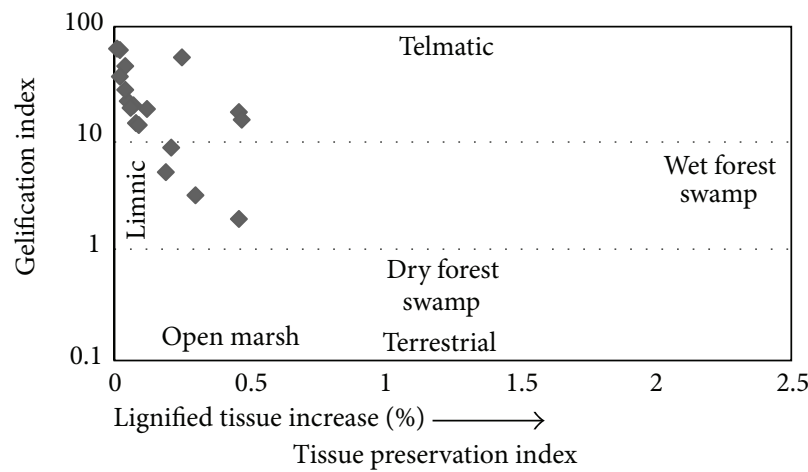

(a)

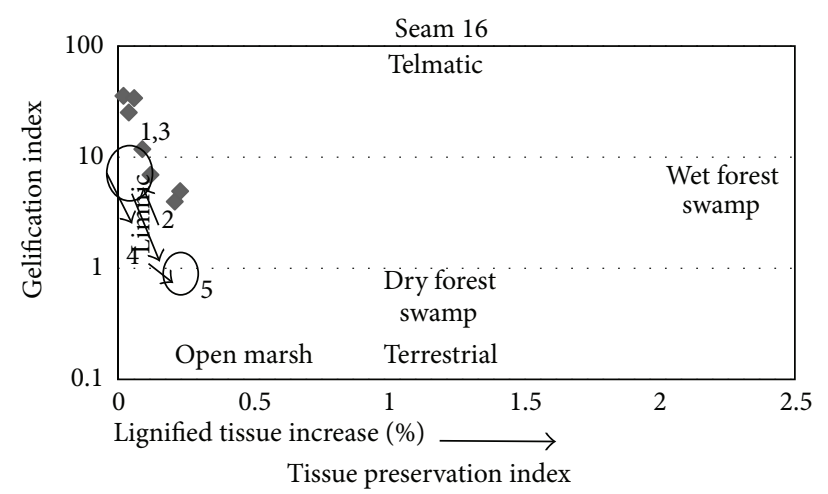

(b)

FIGURE 10: Plots of Tissue Preservation Index and Gelification Index values of Samarinda coal. (a) All seams and (b) Seam 16. Arrows indicate the change of the depositional environment of the studied coal with time. Numbers indicate the phases of the paleomire change.

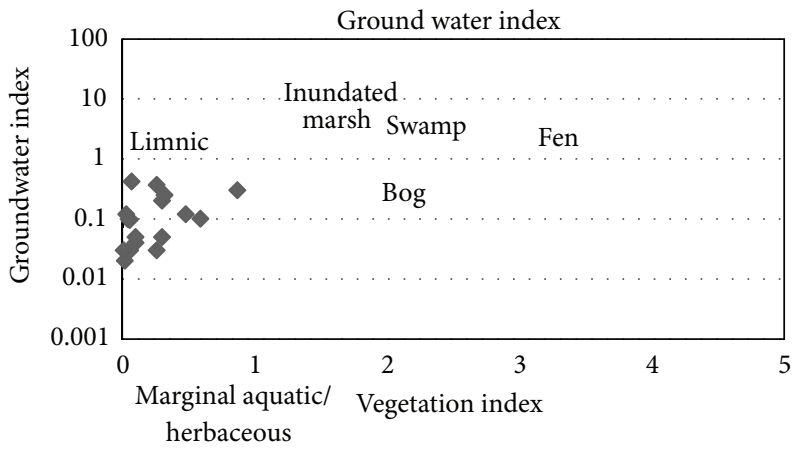

(a)

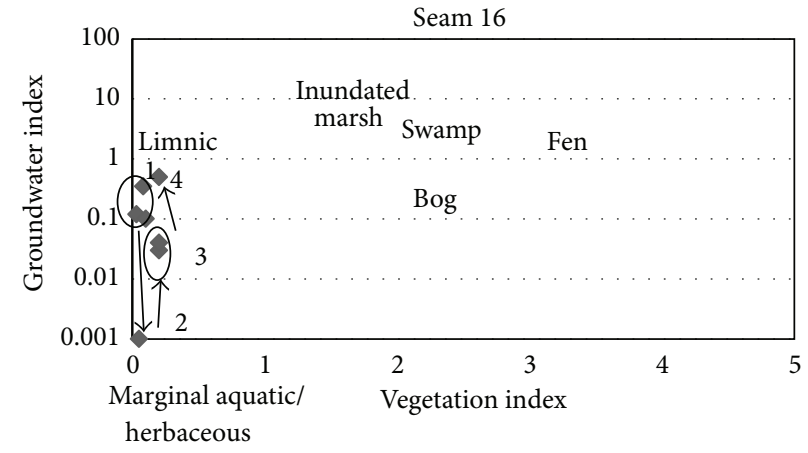

(b)

Figure 11: Plot of Vegetation Index and Groundwater Index values of Samarinda coals on mire paleoenvironment diagram, Calder et al., 1991 [3]. (a) All seams and (b) Seam 16. Arrows indicate the change of the depositional environment of the studied coal with time. Numbers indicate the phases of the paleomire change.

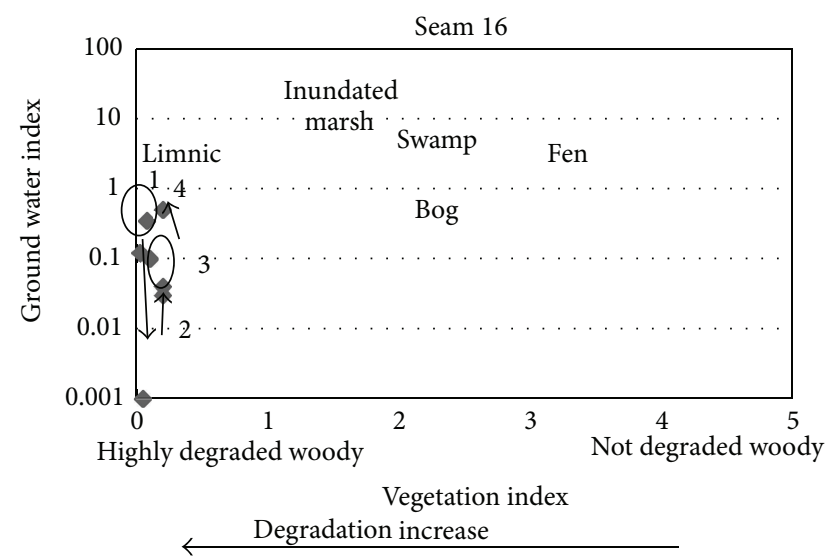

FIGURE 12: Modified plot of Calder et al., 1991 [3] for highly degraded tropical coals.

moor condition with intermittent moderate to high flooding and the paleopeat environment shifted from mesotrophic to ombrotrophic.

\section{Conflict of Interests}

The authors declare that there is no conflict of interests regarding the publication of this paper.

\section{Acknowledgments}

The authors wish to acknowledge the ASEAN University Network Southeast Asia Engineering Education Development Network (AUN/SEED-Net) Program and JICA (Japanese International Cooperation Agency) for financial support.

\section{References}

[1] I. Cibaj, "Fluvial channel complexes in the middle miocene of lower Kutai Basin, East Kalimantan: the stacking pattern of sediments," in Proceedings of Indonesian Petroleum Association 34th Annual Convention and Exhibition, 2010, IPA10-G-053.

[2] I. Cibaj, N. Syarifuddin, U. Ashari, A. Wiweko, and K. Maryunani, "Stratigraphic interpretation of Middle Miocene Mahakam Delta deposits: implications for reservoir distribution and quality," in Proceedings of Indonesian Petroleum Association 31st Annual Convention and Exhibition, IPA07-G-116, 2007. 
[3] J. H. Calder, M. R. Gibling, and P. K. Mukhopadhyay, "Peat formation in a Westphalian B piedmont setting, Cumberland Basin, Nova Scotia: implications for the maceral-based interpretation of rheotrophic and raised paleomires," Bulletin-Societe Geologique de France, vol. 162, no. 2, pp. 283-298, 1991.

[4] A. J. P. Gore, Ed., Mires: Swamp, Bog, Fen and Moor (General Studies): Ecosystems of the World 4A, Elsevier, Amsterdam, The Netherlands, 1983.

[5] P. D. Moore, "Ecological and hydrological aspects of peat formation," in Coal and Coal-Bearing Strata: Recent Advances, A. C. Scott, Ed., Geological Society Special Publication No. 32, pp. 7-15, 1987.

[6] Kusnama, S. A. Mangga, and D. Sukarna, "Tertiary stratigraphy and tectonic evolution of Southern Sumatra," in Proceedings of the Symposium on Tectonic Framework and Energy Resources of the Western Margin of the Pacific Basin, Bulletin Geological Society Malaysia Special Publication no. 33, pp. 143-152, 1993.

[7] J. M. Cole and S. Crittenden, "Early tertiary basin formation and the development of lacustrine and Quasi-lacustrine/marine source rocks on the sunda shelf of SE Asia," in Petroleum Geology of Southeast Asia, A. J. Fraser, S. J. Matthews, and R. W. Murphy, Eds., vol. 126, pp. 147-183, Geological Society London Special Publication, 1997.

[8] M. C. Friederich, R. P. Langford, and T. A. Moore, "The geological setting of Indonesian coal deposits," The AusIMM Proceedings, vol. 304, no. 2, pp. 23-29, 1999.

[9] R. C. Davis, S. W. Noon, and J. Harrington, “The petroleum potential of Tertiary coals from Western Indonesia: relationship to mire type and sequence stratigraphic setting," International Journal of Coal Geology, vol. 70, no. 1-3, pp. 35-52, 2007.

[10] I. M. Longley, "The tectonostratigraphic evolution of SE Asia," in Petroleum Geology of Southeast Asia, A. Fraser, S. Matthews, and R. W. Murphy, Eds., vol. 126, pp. 311-340, Geological Society of London, 1997.

[11] B. Situmorang, C. D. Dwiyoga, and A. Kustamsi, “The untapped "unconventional" gas: CBM resources of Kutai Basin with reference to the North Kutai Lama Field, Sangasanga Area, East Kalimantan," in Proceedings of the International Geosciences Conference and Exhibition, Jakarta, Indonesia, August 2006.

[12] D. H. Land and C. M. Jones, "Coal geology and exploration of part of the Tertiary Kutei Basin in East Kalimantan, Indonesia. Coal and coal-bearing Strata: recent advances," Geological Society Special Publication, no. 32, pp. 235-255, 1987.

[13] C. F. K. Diessel, Coal-Bearing Depositional Systems, Springer, Berlin, Germany, 1992.

[14] G. H. Taylor, M. Teichmüller, A. Davis, C. F. K. Diessel, R. Littke, and P. Robert, Organic Petrology, Gebrüder Borntraeger, Berlin, Germany, 1998.

[15] E. Stach, Stachs Textbook of Coal Petrology, E. Stach, M. Mackowsky, G. H. Teichmiller, D. Taylor, Chandra and R.Teichmiiller, Eds., Gebriidcr Borntraeger, Berlin, Germany, 3rd edition, 1982.

[16] D. L. Marchioni, "Petrography and depositional environment of the Liddell seam, Upper Hunter Valley, New South Wales," International Journal of Coal Geology, vol. 1, no. 1, pp. 35-61, 1980.

[17] M. Smyth, "Coal microlithotypes related to sedimentary environments in the cooper basin," International Association of Sedimentology, vol. 7, pp. 333-347, 1984.

[18] M. P. Singh and P. K. Singh, "Petrographic characterization and evolution of the Permian coal deposits of the Rajmahal basin,
Bihar, India," International Journal of Coal Geology, vol. 29, no. 1-3, pp. 93-118, 1996.

[19] C. F. K. Diessel, “The correlation between coal facies and depositional environments," in Proceedings of 20th Symposium on Advances in the Study of the Sydney Basin, pp. 19-22, The University of Newcastle, Newcastle, Australia, 1986.

[20] A. D. Cohen, W. Spackman, and R. Raymond Jr., "Interpreting the characteristics of coal seams from chemical, physical and petrographic studies of peat deposits," in Coal and Coalbearing Strata: Recent Advances, A. C. Scott, Ed., Geological Society Special Publication No. 32, pp. 107-125, 1987.

[21] R. Littke, "Petrology and genesis of Upper Carboniferous seams from the Ruhr region, West Germany," International Journal of Coal Geology, vol. 7, no. 2, pp. 147-184, 1987.

[22] M. Teichmüller, "The genesis of coal from the viewpoint of coal petrology," International Journal of Coal Geology, vol. 12, no. 1-4, pp. 1-87, 1989.

[23] M. N. Lamberson, R. M. Bustin, and W. Kalkreuth, "Lithotype (maceral) composition and variation as correlated with paleowetland environments, Gates Formation, northeastern British Columbia, Canada," International Journal of Coal Geology, vol. 18, no. 1-2, pp. 87-124, 1991.

[24] R. A. J. Wüst, M. I. Hawke, and R. Marc Bustin, "Comparing maceral ratios from tropical peatlands with assumptions from coal studies: do classic coal petrographic interpretation methods have to be discarded?" International Journal of Coal Geology, vol. 48, no. 1-2, pp. 115-132, 2001.

[25] S. F. Greb, C. F. Eble, J. C. Hower, and W. M. Andrews, "Multiple-bench architecture and interpretations of original mire phases: examples from the Middle Pennyslvanian of the Central Appalachian Basin, USA," International Journal of Coal Geology, vol. 49, no. 2-3, pp. 147-175, 2002.

[26] A. Bechtel, R. F. Sachsenhofer, M. Markic, R. Gratzer, A. Lücke, and W. Püttmann, "Paleoenvironmental implications from biomarker and stable isotope investigations on the Pliocene Velenje lignite seam (Slovenia)," Organic Geochemistry, vol. 34, no. 9, pp. 1277-1298, 2003.

[27] T. Demchuk and T. A. Moore, "Palynofloral and organic characteristics of a Miocene bog-forest, Kalimantan, Indonesia," Organic Geochemistry, vol. 20, no. 2, pp. 119-134, 1993.

[28] J. Dehmer, "Petrology and organic geochemistry of peat samples from a raised bog in Kalimantan (Borneo)," Organic Geochemistry, vol. 20, no. 3, pp. 349-362, 1993.

[29] T. A. Moore, J. C. Shearer, and S. L. Miller, "Fungal origin of oxidised plant material in the Palangkaraya peat deposit, Kalimantan Tengah, Indonesia: implications for 'inertinite' formation in coal," International Journal of Coal Geology, vol. 30, no. 1-2, pp. 1-23, 1996.

[30] A. D. Cohen and W. Spackman, "Methods in peat petrology and their application to reconstruction of Paleoenvironments," Bulletin of the Geological Society of America, vol. 83, no. 1, pp. 129-142, 1972.

[31] W. C. Grady, C. F. Eble, and S. G. Neuzil, "Brown coal maceral distributions in a modern domed tropical Indonesian peat and a comparison with maceral distributions in Middle Pennsylvanian-age Appalachian bituminous coal beds," Geological Society of America, Special Paper 286, pp. 63-82, 1993.

[32] M. I. Hawke, I. P. Martini, and L. D. Stasiuk, "Petrographic characteristics of selected Ontario peats: possible modern analogues for coals," in Proceedings of the 13th Annual Meeting TSOP Abstracts and Program, pp. 22-23, Southern Illinois University, Carbondale, Ill, USA, 1996. 
[33] M. I. Hawke, I. P. Martini, and L. D. Stasiuk, "A comparison of temperate and Boreal peats from Ontario, Canada: possible modern analogues for Permian coals," International Journal of Coal Geology, vol. 41, no. 3, pp. 213-238, 1999.

[34] J. C. Shearer and B. R. Clarkson, "Whangamarino wetland: effects of lowered river levels on peat and vegetation," International Peat Journal, vol. 8, pp. 52-65, 1998.

[35] W. B. Styan and R. M. Bustin, "Petrographyof some fraser river delta peat deposits: coal maceral and microlithotype precursors in temperate-climate peats," International Journal of Coal Geology, vol. 2, no. 4, pp. 321-370, 1983.

[36] B. U. Haq, J. Hardenbol, and P. R. Vail, "Chronology of fluctuating sea levels since the Triassic," Science, vol. 235, no. 4793, pp. 1156-1167, 1987.

[37] W. Kalkreuth, T. Kotis, C. Papanicolaou, and P. Kokkinakis, "The geology and coal petrology of a Miocene lignite profile at Meliadi Mine, katerini, Greece," International Journal of Coal Geology, vol. 17, no. 1, pp. 51-67, 1991.

[38] N. G. Obaje, B. Ligouis, and S. I. Abaa, "Petrographic composition and depositional environments of Cretaceous coals and coal measures in the Middle Benue Trough of Nigeria," International Journal of Coal Geology, vol. 26, no. 3-4, pp. 233260, 1994

[39] H. Amijaya and R. Littke, "Microfacies and depositional environment of Tertiary Tanjung Enim low rank coal, South Sumatra Basin, Indonesia," International Journal of Coal Geology, vol. 61, no. 3-4, pp. 197-221, 2005.

[40] W. Gruber and R. F. Sachsenhofer, "Coal deposition in the Noric depression (Eastern Alps): raised and low-lying mires in Miocene pull-apart basins," International Journal of Coal Geology, vol. 48, no. 1-2, pp. 89-114, 2001.

[41] I. P. Martini and W. Glooschenko, "Cold climate environments of peat formation in Canada. Advances in the Study of the Sydney Basin," in Proceedings of the 18th Newcastle Symposium Proceeding, pp. 18-28, 1984.

[42] E. Polak, "Ueber Torf und Moor in Nieder landisch," Koninklijke Akademie van Wetenschappen, vol. 30, pp. 1-85, 1933.

[43] B. Polak, "Character and occurrence of peat deposits in the Malaysian tropics," Modern Quaternary Research in Southeast Asia, vol. 2, pp. 71-81, 1975.

[44] F. Merton, "A visit to Tasek Bera," Malayan Nature Journal, vol. 16, pp. 103-110, 1962.

[45] J. A. R. Anderson, "Observations on the ecology of five peat swamp forests in Sumatra and Kalimantan," in Peat and Podzolic Soils and Their Potential for Agriculture in Indonesia, pp. 45-55, Tugu, Indonesia, 1976.

[46] J. A. R. Anderson, "The tropical peat swamps of Western Malesia," in Mires: Swamp, Bog, Fen and Moor, Regional Studies: Ecosystems of the World, A. J. P. Gore, Ed., pp. 181-199, Elsevier, Amsterdam, The Netherlands, 1983.

[47] R. J. Morley, "Origin and history of Tasek Bera," in Tasik Bera: The Ecology of a Freshwater Swamp. Monographiae Biologicae, J. I. Furtado and S. Mori, Eds., pp. 12-45, Dr. W. Junk Publishers, The Hague, The Netherlands, 1982.

[48] Frim, "A consultancy report on the extent and types of vegetation cover at Tasek Bera," Forest Research Institute of Malaysia for Wetlands International-Asia Pacific, Kuala Lumpur, Malaysia, 1997.

[49] W. Giesen, The Habitats and Flora of Tasik Bera, Malaysia: An Evaluation of Their Conservation Value and Management Requirements, Wetlands International-Asia Pacific, Kuala Lumpur, Malaysia, 1998.
[50] S. Phillips and R. M. Bustin, "Accumulation of organic rich sediments in a dendritic fluvial/lacustrine mire system at Tasik Bera, Malaysia: implications for coal formation," International Journal of Coal Geology, vol. 36, no. 1-2, pp. 31-61, 1998.

[51] R. A. J. Wüst and R. M. Bustin, Geological and Ecological Evolution of the Tasek Bera (Peninsular-Malaysia) Wetland Basin Since the Holocene: Evidences of a Dynamic System From Siliciclastic and Organic Sediments, Wetlands International-Asia Pacific, Kuala Lumpur, Malaysia, 1999.

[52] K. E. Barber, "Peatlands as scientific archives of past biodiversity," Biodiversity and Conservation, vol. 2, no. 5, pp. 474-489, 1993.

[53] W. H. Orem, S. G. Neuzil, H. E. Lerch, and C. B. Cecil, "Experimental early-stage coalification of a peat sample and a peatified wood sample from Indonesia," Organic Geochemistry, vol. 24, no. 2, pp. 111-125, 1996.

[54] T. Kuder, M. A. Kruge, J. C. Shearer, and S. L. Miller, "Environmental and botanical controls on peatification: a comparative study of two New Zealand restiad bogs using Py-GC/MS, petrography and fungal analysis," International Journal of Coal Geology, vol. 37, no. 1-2, pp. 3-27, 1998.

[55] R. J. Morley, "Development and vegetation dynamics of a lowland ombrogenous peat swamp in Kalimantan Tengah, Indonesia," Journal of Biogeography, vol. 8, pp. 383-404, 1981.

[56] C. C. Cameron, J. S. Esterle, and C. A. Palmer, "The geology, botany and chemistry of selected peat-forming environments from temperate and tropical latitudes," International Journal of Coal Geology, vol. 12, no. 1-4, pp. 105-156, 1989.

[57] T. A. Moore and J. C. Ferm, "Composition and grain size of an Eocene coal bed in Southeastern Kalimantan, Indonesia," International Journal of Coal Geology, vol. 21, pp. 1-30, 1992.

[58] P. K. Singh, M. P. Singh, A. K. Singh, and M. Arora, "Petrographic characteristics of coal from the Lati Formation, Tarakan basin, East Kalimantan, Indonesia," International Journal of Coal Geology, vol. 81, no. 2, pp. 109-116, 2010.

[59] R. J. Morley, "Palynological evidence for tertiary plant dispersals in the SE Asian region in relation to plate tectonics and climate," in Biogeography and Geological Evolution of SE Asia, R. Hall and J. D. Holloway, Eds., pp. 211-234, Backhuys, Leiden, The Netherlands, 1998.

[60] R. J. Morley, "Tertiary ecological history of Southeast Asian peat mires," in Proceedings of Southeast Coal Geology Conference, pp. 44-47, Directorate General of Geology and Mineral Resources of Indonesia, Bandung, Indonesia, 2000.

[61] S. G. Neuzil, C. C. B. Supardi, J. S. Kane, and K. Soedjono, "Inorganic Geochemistry of domed peat in Indonesia and its implication for the origin of mineral matter in coal," in Modern and Ancient Coal-Forming Environment, J. C. Cobb and C. B. Cecil, Eds., Geological Society of America Special Paper 286, pp. 23-84, 1993.

[62] J. S. Esterle and J. C. Ferm, "Spatial variability in modern tropical peat deposits from Sarawak, Malaysia and Sumatra, Indonesia: analogues for coal," International Journal of Coal Geology, vol. 26, no. 1-2, pp. 1-41, 1994.

[63] J. Dehmer, "Petrological and organic geochemical investigation of recent peats with known environments of deposition," International Journal of Coal Geology, vol. 28, no. 2-4, pp. 111-138, 1995.

[64] K. Anggayana, Mikroskopische und organisch-geochemische Untersuchungen an Kohlen aus Indonesien, ein Beitrag zur Genese und Fazies verschiedener Kohlenbecken [Ph.D. thesis], RWTH, Aachen, Germany, 1996. 
[65] C. Nas and A. Pujobroto, "Vitrinite macerals in Indonesian coal," in Proceedings of Southeast Coal Geology Conference, pp. 215-226, Directorate General of Geology and Mineral Resources of Indonesia, Bandung, Indonesia, 2000.

[66] P. J. Crosdale, "Coal maceral ratios as indicators of environment of deposition: do they work for ombrogenous mires? An example from the Miocene of New Zealand," Organic Geochemistry, vol. 20, no. 6, pp. 797-809, 1993.

[67] A. C. Scott, "Coal petrology and the origin of coal macerals: a way ahead?” International Journal of Coal Geology, vol. 50, no. 1-4, pp. 119-134, 2002.

[68] T. A. Moore and J. C. Shearer, "Peat/coal type and depositional environment-are they related?" International Journal of Coal Geology, vol. 56, no. 3-4, pp. 233-252, 2003. 

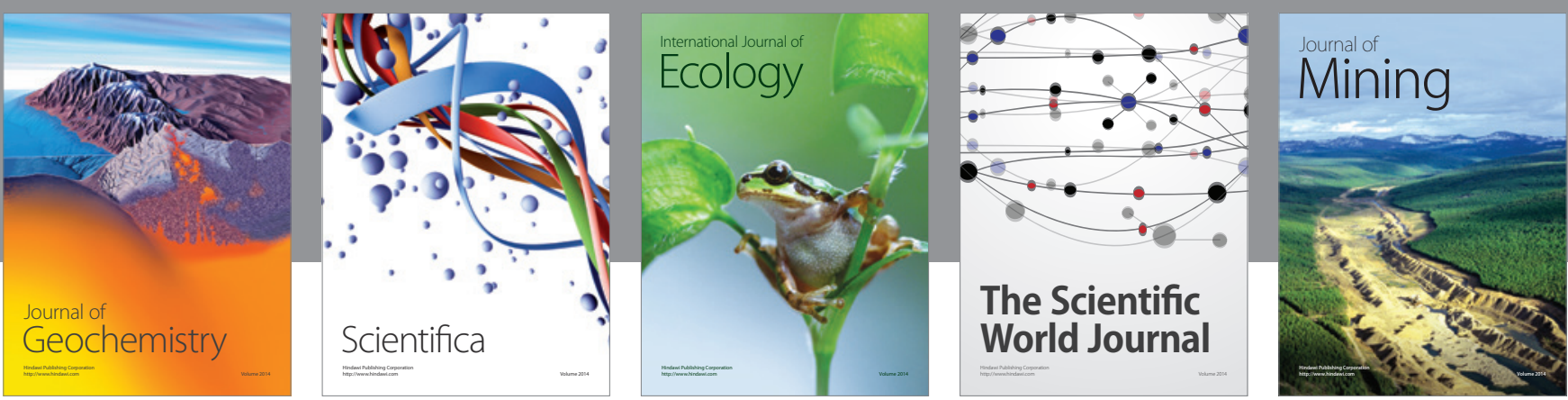

The Scientific World Journal
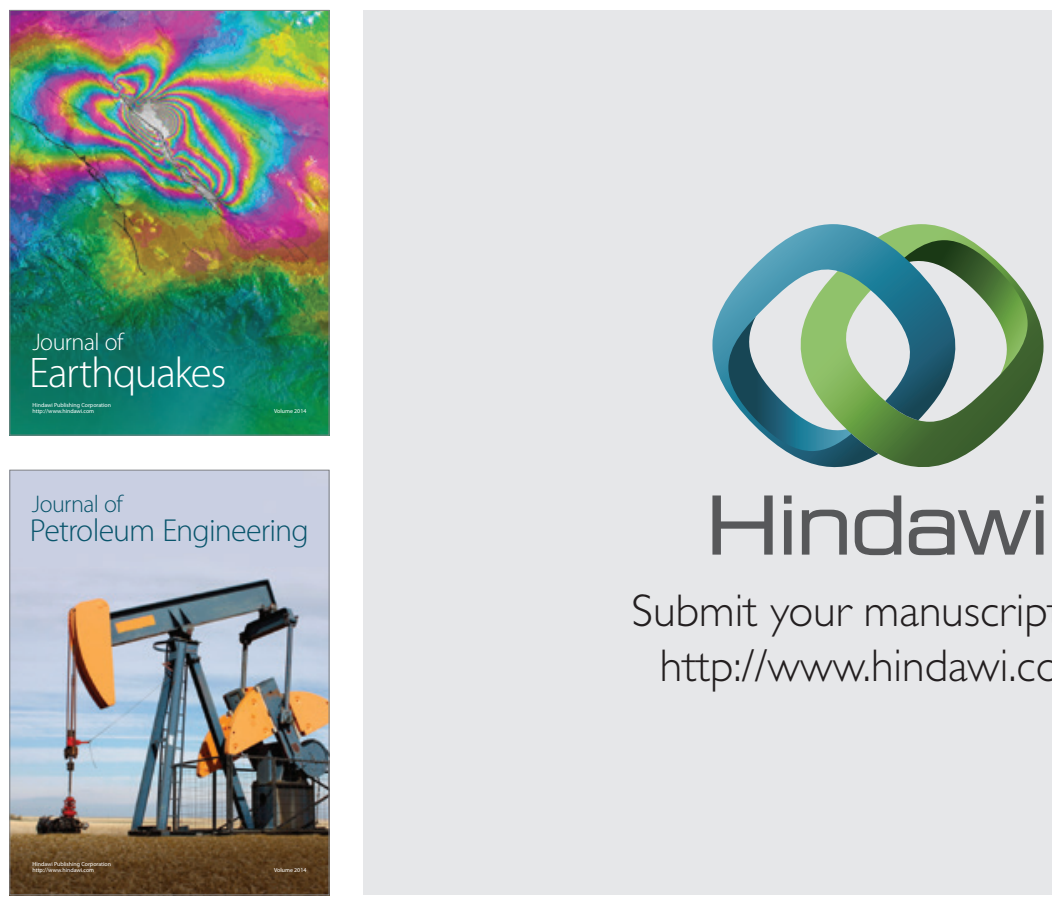

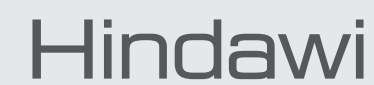

Submit your manuscripts at

http://www.hindawi.com
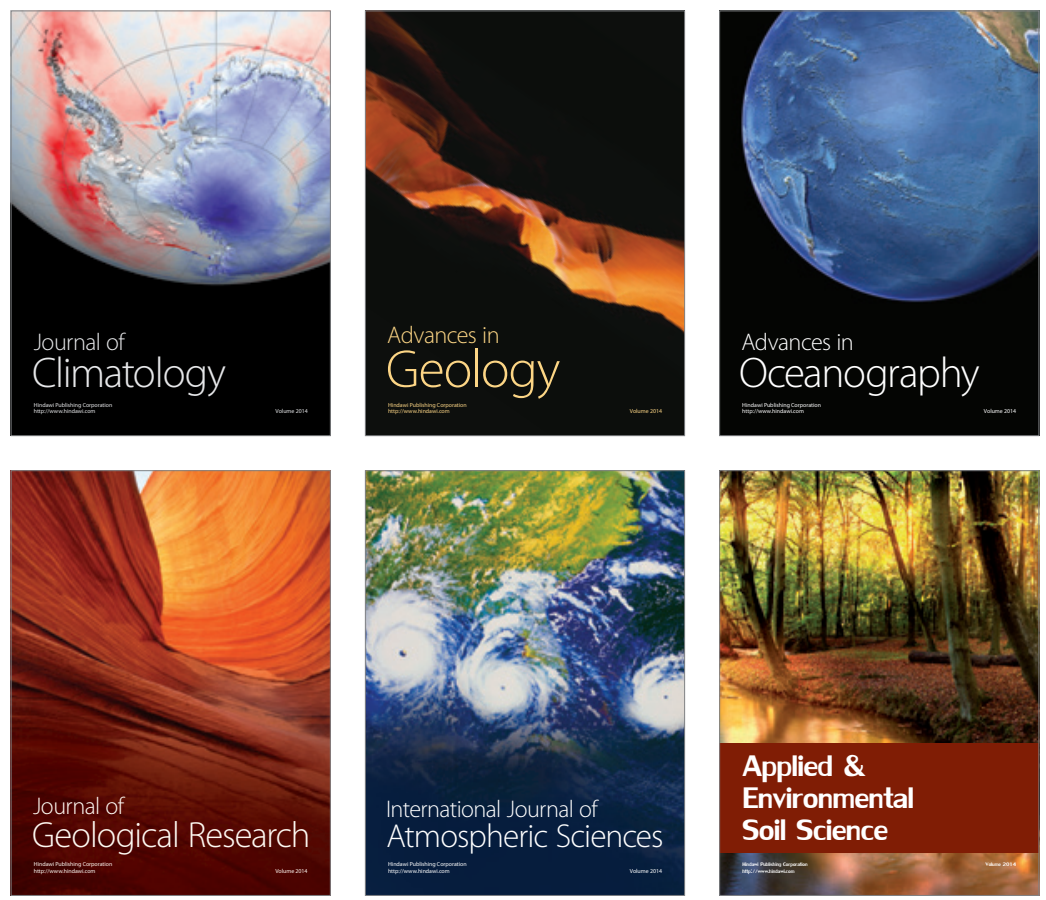
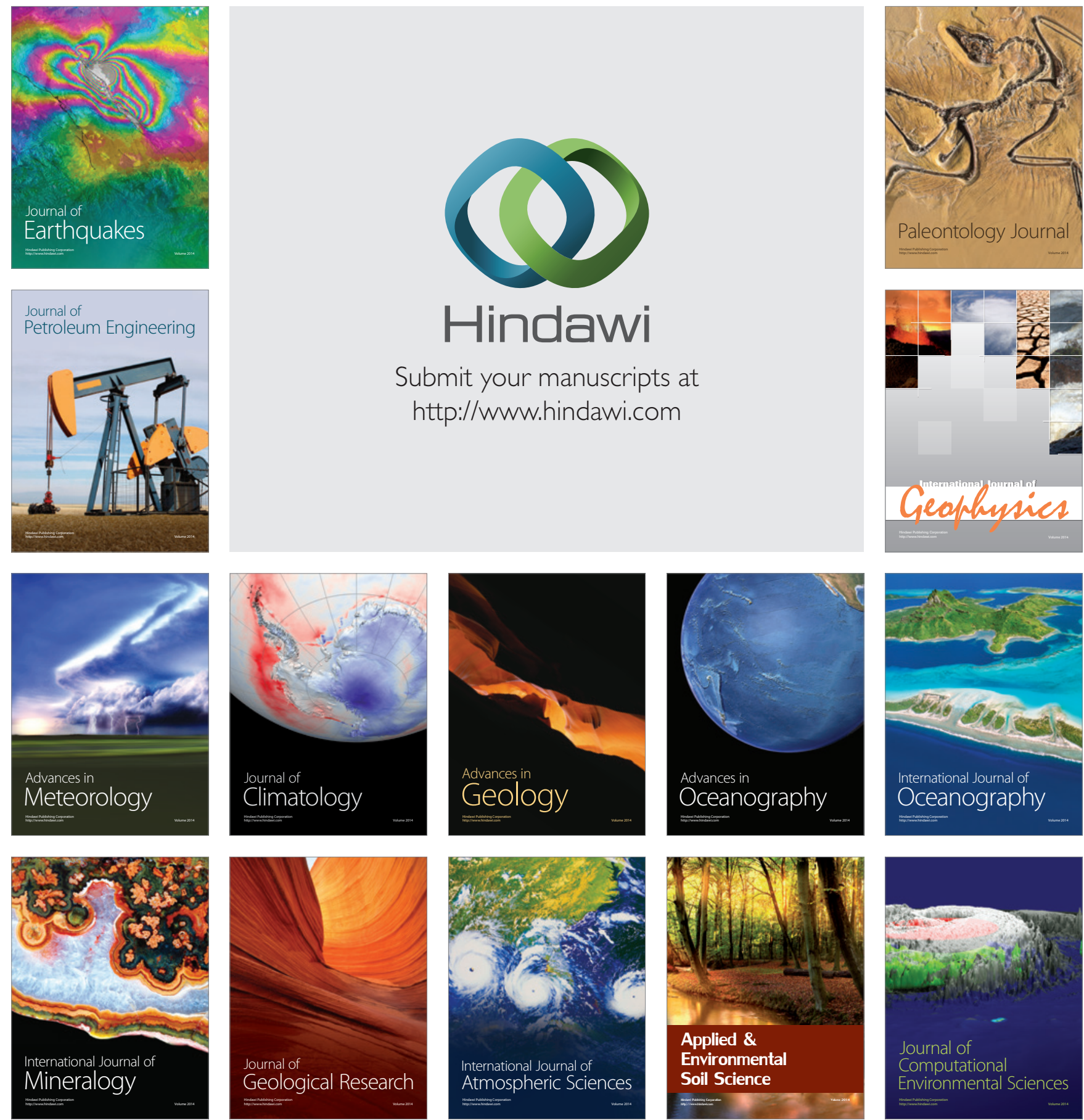